\title{
Fluorinated Phenanthrenes as Aryne Precursors: PAH Synthesis Based on Domino Ring Assembly Using 1,1-Difluoroallenes
}

\author{
Kohei Fuchibe, ${ }^{[a]}$ Masashi Abe, ${ }^{[a]}$ Hiroto Idate, ${ }^{[a]}$ and Junji Ichikawa*[a] \\ Dedicated to the 100th Annual Meeting of the CSJ
}

[a] Dr. K. Fuchibe, M. Abe, H. Idate and Prof. Dr. J. Ichikawa
Division of Chemistry, Faculty of Pure and Applied Sciences, University of Tsukuba
Tsukuba, Ibaraki 305-8571 (Japan)
E-mail: junji@chem.tsukuba.ac.jp
Supporting information for this article is given via a link at the end of the document.

\begin{abstract}
On treatment with the catalyst, $\operatorname{InBr}_{3}, 1$,1-difluoroallenes that bear a cyclopentene moiety and an aryl group underwent domino ring assembly in the presence or absence of $\mathrm{N}$ bromosuccinimide or $\mathrm{N}$-iodosuccinimide to afford aryne precursors such as three-ringed ortho-fluoro(halo)phenanthrenes, four-ringed ortho-fluoro(halo)tetraphenes, ortho-fluoro(halo)chrysenes and fluoro[4]helicenes. Metalation of the aryne precursors followed by elimination of the fluoride resulted in the unprecedented systematic generation of arynes bearing $\pi$-extended systems. Diels-Alder reactions of these arynes with isobenzofurans afforded the corresponding cycloadducts whose reductive aromatisation in an $\mathrm{SnCl}_{2} / \mathrm{HBr}$ system furnished fully aromatised benzotriphenylenes. In addition, oxidative aryl-aryl coupling (the Scholl reaction) of these benzotriphenylenes facilitated the synthesis of 'half HBCs' (hexabenzocoronenes).
\end{abstract}

\section{Introduction}

Polycyclic aromatic hydrocarbons (PAHs), which are a family of compounds consisting of benzene rings fused in various configurations, ${ }^{[1]}$ have attracted considerable attention recently because of their viability as organic electronic materials. ${ }^{[2]}$ With their linear benzene ring configuration, acenes are one of the most representative types of PAHs (Figure 1) and are known to
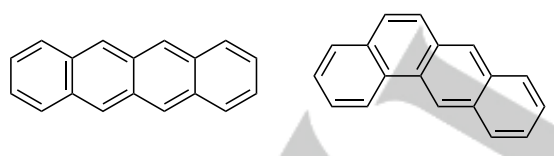

Acenes (naphthacene)

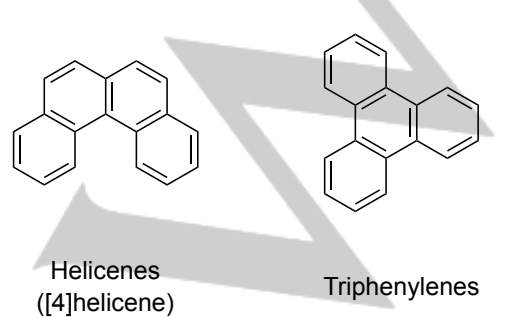

Figure 1. Major Families of PAHs. be excellent organic semiconducting materials. ${ }^{[3]}$ Aphenes possess a bent configuration, which is one of core structures in PAHs. Known for their zig-zag configuration, phenacenes have experienced a resurgence in popularity as air-stable organic semiconductors ${ }^{[4]}$ and their $\mathrm{O}_{2}$-sensing properties are fascinating to research chemists. ${ }^{[5]}$ Helicenes are optical and electronic materials $^{[6]}$ with unique chirality-derived characteristics. ${ }^{[7]}$ In addition to these topologically one-dimensional molecules, both triphenylenes with their topologically two-dimensional configuration and circulenes, which possess a cyclic configuration, have been used for applications in materials and supramolecular chemistry, ${ }^{[8]}$ particularly since they both contain discotic columnar structures in their crystals, which make them excellent materials for use as liquid crystals, in OFETs and for the construction of photovoltaic cells.

Arynes have a formal triple bond within their six-membered ring, thus making them useful tools for the synthesis of fused benzene ring structures. ${ }^{[9]}$ However, with the exception of didehydronaphthalenes and didehydrophenanthrenes, ${ }^{\left[{ }^{[c]}\right]}$ the synthetic uses of these types of $\pi$-extended arynes have been still limited. ${ }^{[9 c, d][10]}$

One primary shortcoming of $\pi$-extended arynes lies in the preparation of their precursors. In order for arynes to be useful as starting materials for $\pi$-extended PAHs, the synthetic routes to their respective precursors must facilitate both the construction of $\pi$-systems and the introduction of functional groups (MG and LG in Figure 2).

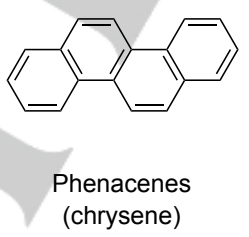<smiles>Cc1cc(C)c(C(=O)Cl)cc1C</smiles>

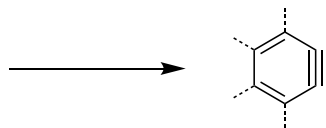

Figure 2. $\pi$-Extended Arynes and Their Precursors (MG = Metalation Group, $\mathrm{LG}=$ Leaving Group).

Previously, we reported on In-catalysed domino cyclisation/ring expansion sequences using 1,1-difluoroallenes 1 (Scheme 1). ${ }^{[11,12]}$ Difluoroallenes bearing a cyclopentene moiety and an aryl group were treated with $\operatorname{lnBr}_{3}$ catalyst to generate the localized difluoroallylic cations in which stabilisation was achieved by the transfer of a lone pair of electrons from fluorine to a vacant carbon $p$ orbital (i.e. the $\alpha$-cation stabilising effect of fluorine substituents). ${ }^{[13,14]}$ Here, the In-substituted allylic cations readily underwent a regioselective Friedel-Crafts-type cyclisation followed by ring expansion to afford pinpoint- 
fluorinated PAHs 2. Noteworthy is that when the reaction was performed in the presence of a halogenating agent such as NBS ( $\mathrm{N}$-bromosuccinimide) or NIS ( $\mathrm{N}$-iodosuccinimide), the carbonindium bond facilitated halogenation, thus affording orthofluoro(halo)phenanthrene analogues of $\mathbf{3}$ that could be subsequently transformed into their respective arynes via dehalogenation.

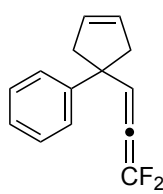

1

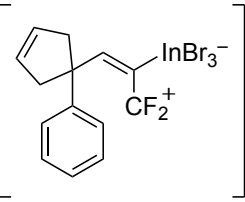

localized allylic cations

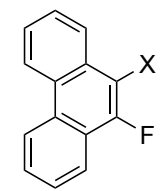

w/o NBS or NIS $2(X=H)$

w/ NBS or NIS $\mathbf{3}(X=\mathrm{Br}$ or I)

Scheme 1. Domino Cyclisation/Ring Expansion/Halogenation of 1,1Difluoroallenes 1.

Thus, we envisioned that the domino cyclisation/ring expansion/halogenation sequence would open a route to the systematic synthesis of $\pi$-extended arynes. In this paper, the synthesis of ortho-bromo(fluoro)phenanthrenes, orthobromo(fluoro)chrysenes and ortho-bromo(fluoro)tetraphenes and their respective iodo analogues are described. Also discussed are Diels-Alder reactions of isobenzofurans with the in situgenerated didehydrophenanthrene, didehydrochrysene and didehydrotetraphene, two of which were composed of four benzene rings, as well as their subsequent reductive aromatisation to the respective benzotriphenylene derivatives. ${ }^{[15]}$ Furthermore, arynes bearing a [4]helicene framework were generated from fluorohelicene via dehydrofluorination; this reaction resulted in the corresponding benzotriphenylenes. Finally, the most suitable products were subjected to oxidative aryl-aryl coupling (the Scholl reaction) ${ }^{[16]}$ to facilitate the synthesis of half hexabenzocoronenes (HBCs). ${ }^{[17]}$

\section{Results and Discussion}

Preparation of ortho-fluoro(halo)arenes (phenanthrenes, tetraphenes and chrysenes) and fluoro[4]helicenes. orthoFluoro(halo)phenanthrenes, -tetraphenes and -chrysenes 3 were prepared via domino ring assembly of 1,1-difluoroallenes (Scheme 2). First, 1,1-difluoroallenes bearing a cyclopentene moiety and an aryl group (1a-1c) were prepared from arylacetonitriles via (i) an initial double allylation for the construction of the five-membered ring. (ii) A subsequent partial reduction was carried out, followed by (iii) difluorovinylidenation of the resulting aldehydes (not shown). ${ }^{[12 b]}$ Difluoroallenes, including $\mathbf{1 b}$ and $1 \mathrm{c}$, with an additional benzo moiety on either the $P$ or $Q$ site (Scheme 2) were treated with $4 \mathrm{~mol} \%$ of $\operatorname{InBr}_{3}$ in the presence of NBS (1.2 equiv) or NIS (1.2 equiv) followed by a one-pot dehydrogenation using DDQ. Domino cyclisation/ring expansion/halogenation (via bromination or iodination) afforded
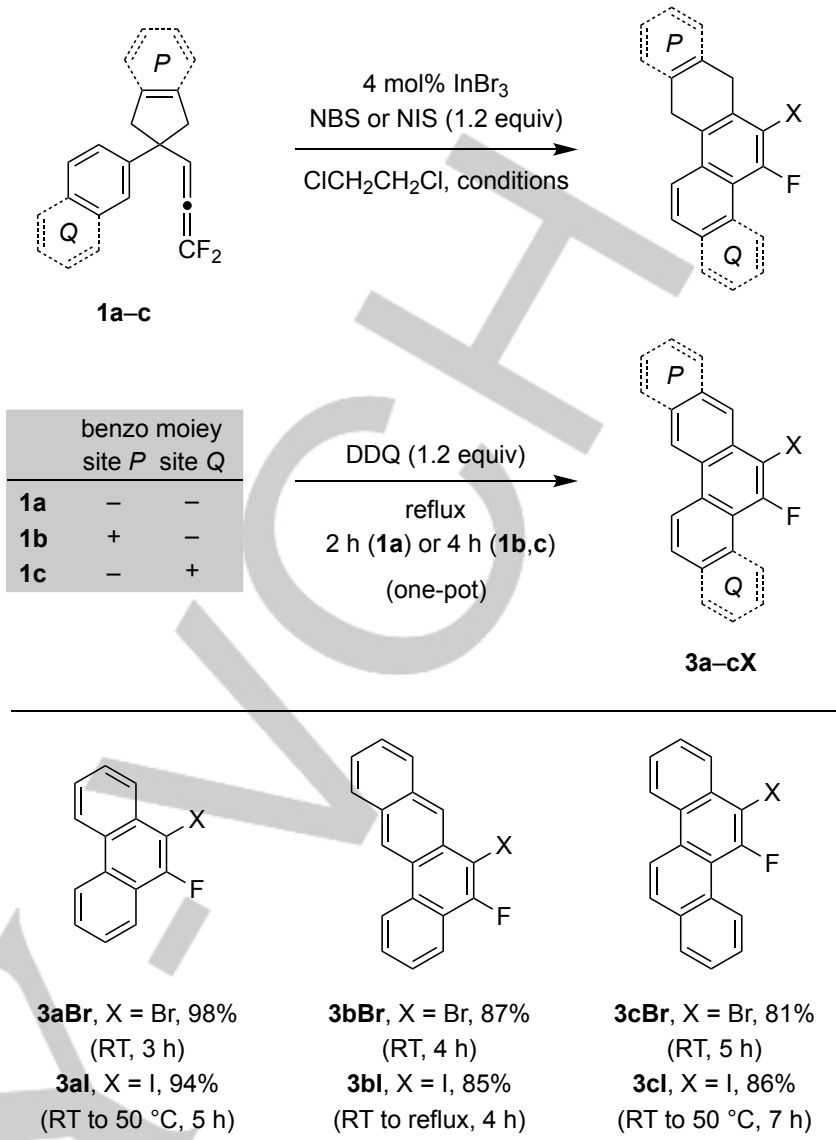

Scheme 2. Preparation of ortho-Fluoro(halo)arenes 3 (Aryne Precursors)

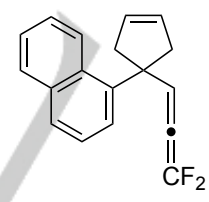

1d

\begin{tabular}{|c|c|}
\hline $2 \mathrm{~mol} \% \mathrm{InBr}_{3}$ & DDQ (1.2 equiv) \\
\hline $\mathrm{ClCH}_{2} \mathrm{CH}_{2} \mathrm{Cl}, \mathrm{RT}$ & reflux, $2 \mathrm{~h}$ \\
\hline $30 \mathrm{~min}$ & (one pot) \\
\hline
\end{tabular}<smiles>Fc1cc2ccccc2c2c1ccc1ccccc12</smiles>

2d, $60 \%$

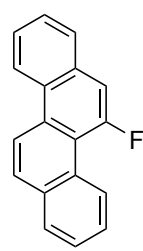

$20 \%$ the desired ortho-fluoro(halo)phenanthrenes $3 \mathrm{aBr}$ (98\% yield) and 3 al (94\% yield), fluoro(halo)tetraphenes $3 \mathrm{bBr}$ ( $87 \%$ yield) and $\mathbf{3 b l}$ ( $85 \%$ yield) and, lastly, fluoro(halo)chrysenes $\mathbf{3 c B r}$ ( $81 \%$ yield) and $\mathbf{3 c l}$ (86\% yield). Fluoro[4]helicene, 2d, was prepared as shown in Eq 1. ${ }^{[18]}$

Generation of Arynes A-D and Their Diels-Alder Reactions. To construct the benzene rings, the arynes underwent DielsAlder reactions using isobenzofurans as the dienes. The isobenzofurans $\mathbf{4 a - f}$ (Figure 3) were easily prepared from commercially available methyl o-formylbenzoate and the corresponding arylmagnesium bromides (2.3 equiv) via the method reported by Hamura. ${ }^{[19]}$ 
<smiles>Brc1oc(Br)c2ccccc12</smiles>

\begin{tabular}{llll}
\multicolumn{4}{c}{$\mathrm{Ar}$} \\
\hline 4a & $\mathrm{Ph}$ & 4d & $\mathrm{C}_{6} \mathrm{H}_{4} p-t-\mathrm{Bu}$ \\
4b & $\mathrm{C}_{6} \mathrm{H}_{4} p-\mathrm{OMe}$ & $\mathbf{4 e}$ & $\mathrm{C}_{6} \mathrm{H}_{4} p-\mathrm{F}$ \\
4c & $\mathrm{C}_{6} \mathrm{H}_{4} p-n-\mathrm{Hex}$ & $\mathbf{4 f}$ & $2-$ Thienyl
\end{tabular}

Figure 3. Analogues of Isobenzofurans 4

In the presence of isobenzofuran $\mathbf{4 a}$, bromo(fluoro)phenanthrene $3 \mathrm{aBr}$ was treated with butyllithium $\left(1.2\right.$ equiv) at $-90^{\circ} \mathrm{C}$, which allowed for $\mathrm{Li}-\mathrm{Br}$ exchange to take place followed by $\mathrm{LiF}$ elimination to generate the desired aryne. ${ }^{[20]}$ After warming to RT, the adduct 5 aa was obtained in $55 \%$ yield along with fluorophenanthrene $\mathbf{2 a}$ in $24 \%$ yield (Entry 1, Table 1). Thus, it was clear that the intermediate 13,14-didehydrophenanthrene (phenanthryne) (A) was generated to undergo Diels-Alder reaction with $4 a$. Deuterium labelling experiments $\left(D_{2} \mathrm{O}\right.$ quench) performed under identical reaction conditions indicated that no deuterium had been incorporated into the structure of $2 a$ (as determined by ${ }^{1} \mathrm{H}$ NMR). This meant that protonation was a competitive process in the reaction medium, especially in the presence of THF.<smiles>Fc1c(Br)c2ccccc2c2ccccc12</smiles>

$3 \mathrm{aBr}$<smiles>c1ccc(-c2oc(-c3ccccc3)c3ccccc23)cc1</smiles>

$4 a$

\section{$\underset{\mathrm{Et}_{2} \mathrm{O}-\mathrm{THF}(4: 1), 2 \mathrm{~h}}{\stackrel{n \text {-BuLi }(1.2 \text { equiv) }}{\longrightarrow}}$
$-\mathrm{LiBr},-\mathrm{LiF}$}

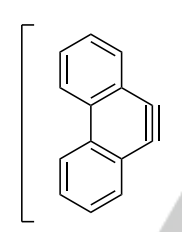

phenanthryne A

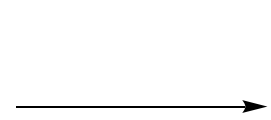<smiles></smiles>

5 aa

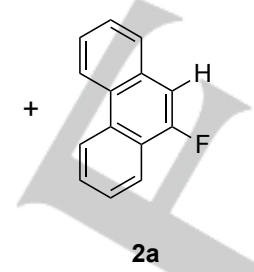

Table 1. Generation and Diels-Alder Reaction of Aryne A.

\begin{tabular}{lllll}
\hline Entry & 4a [equiv] & Temperature & 5aa [\%] ${ }^{[\mathrm{a}]}$ & 2a [\%] ${ }^{[\mathrm{a}]}$ \\
\hline 1 & 1.2 & $-90{ }^{\circ} \mathrm{C}$ to RT & 55 & 24 \\
2 & 1.2 & RT & 66 & 9 \\
3 & 2.0 & RT & 84 & 8 \\
\hline
\end{tabular}

[a] ${ }^{1} \mathrm{H}$ NMR yield based on an internal standard $\mathrm{CH}_{2} \mathrm{Br}_{2}$.

In order to boost the elimination of lithium fluoride from the intermediary fluoro(lithio)phenanthrene, the reaction was performed at room temperature (Entry 2 ). Here, the $\mathbf{5 a} \mathbf{a} / \mathbf{2 a}$ ratio increased significantly, and 5 aa was obtained in $66 \%$ yield. By using 2.0 equiv of $\mathbf{4 a}$, the yield of 5 aa was improved to $84 \%$ (Entry 3). Diels-Alder reactions of $\mathbf{3}$ with several other isobenzofurans were conducted under the aforementioned conditions (Table 2). Phenanthryne A underwent Diels-Alder reaction to afford the desired adducts 5aa-5af in 67\%-89\% yields. Similar reactions were also conducted using $\pi$-extended $3 \mathrm{bBr}$ and $3 \mathrm{cBr}$ with $4 \mathrm{a}$ in which the reactions proceeded via the intermediates 5,6-didehydrotetraphene B and 5,6- didehydrochrysene C (Figure 4) to afford the oxygenated benzotriphenylene analogues $\mathbf{5 b a}$ and $\mathbf{5 c a}$ in $88 \%$ and $94 \%$ yields, respectively (Eqs 2 and 3 ).<smiles>Fc1c(Br)c2ccccc2c2ccccc12</smiles>

$3 \mathrm{aBr}$

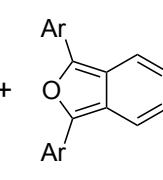

4 (2.0 equiv) via $\mathbf{A}$

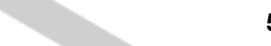

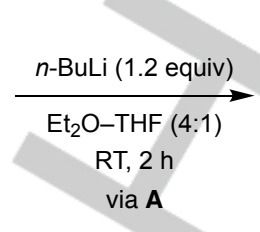

Table 2. Diels-Alder Reaction between Phenanthryne A and Isobenzofurans 4.

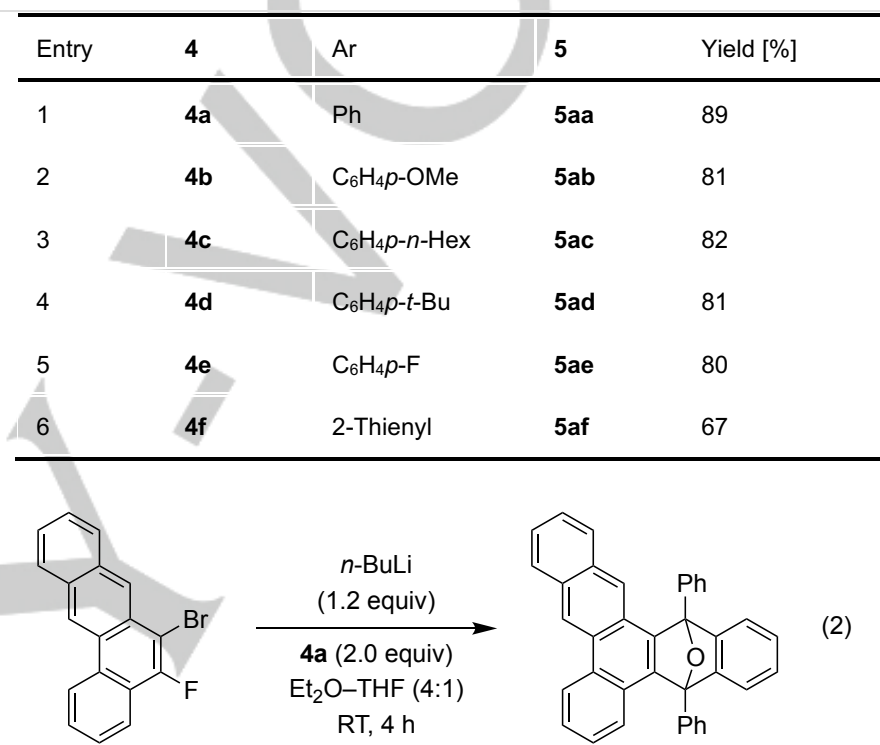

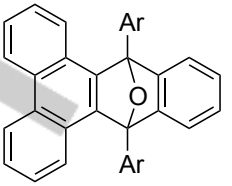<smiles>Fc1c(Br)c2ccccc2c2ccc3ccccc3c12</smiles>

$3 \mathrm{cBr}$<smiles>c1c2ccccc2c2cc3ccccc3cc2c#1</smiles>

5,6-didehydrotetraphene $\mathbf{B}$ via B

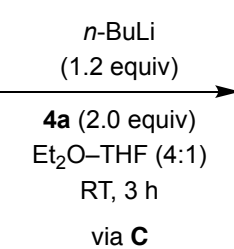

via C

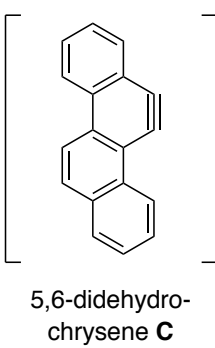

5 ba, $88 \%$<smiles></smiles>

5ca, $94 \%$<smiles></smiles>

5,6-didehydro[4]helicene D

Figure 4. Generated $\pi$-Extended Arynes B-D

Although deprotonation of fluorohelicene $\mathbf{2 d}$ with butyllithium afforded the Diels-Alder adduct $\mathbf{5 d a}$ in low yield $(56 \%)$, the use of $\mathrm{Me}_{2}(\mathrm{TMP}) \mathrm{ZnLi}$ dramatically improved the yield of $\mathbf{5 d a}$ (Scheme 3). ${ }^{[21]}$ Treatment of $\mathbf{2 d}$ with $\mathrm{Me}_{2}(\mathrm{TMP}) \mathrm{ZnLi}(4.0$ equiv) in the presence of $4 \mathrm{a}$ (THF, reflux, $1.5 \mathrm{~h}$ ) afforded $\mathbf{5 d a}$ in $93 \%$ yield. 


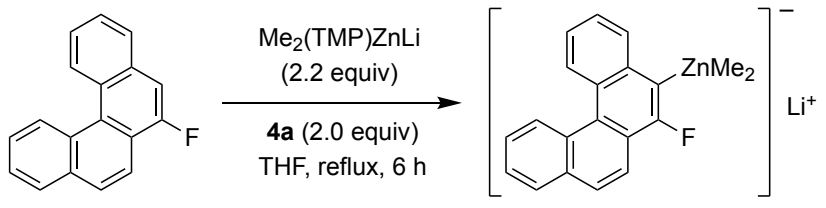

2d

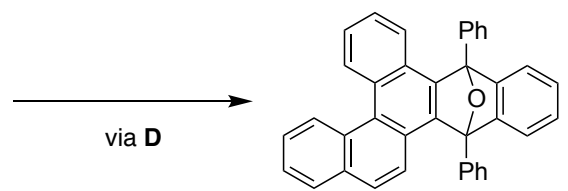

5da, $93 \%$

Scheme 3. Diels-Alder Reaction of Didehydrohelicene D and Isobenzofurans 4 (TMP = tetramethylpiperidino).

Reductive Aromatisation of the Diels-Alder Adducts 5 . Reductive aromatisation of the adduct $\mathbf{5}$ aa to benzotriphenylene 6aa proceeded under basic conditions (Scheme 4). Low-valent titanium species generated from $\mathrm{TiCl}_{3}$ and butyllithium promoted aromatisation to afford $6 \mathbf{a a}$ in $92 \%$ yield. The low-valent titanium species were also generated from $\mathrm{Cp}_{2} \mathrm{TiCl}_{2} /$ butyllithium and from $\mathrm{TiCl}_{4} / \mathrm{Zn}$, both of which afforded 6 aa in $90 \%$ and $72 \%$ yields, respectively. Although successful with $\mathbf{5 a a}$, aromatisation using the latter two reagent systems was ineffective when applied to other $\pi$-extended analogues of $\mathbf{5}$, whereas the former two reagent systems were strongly basic. Thus, further examination was carried out.

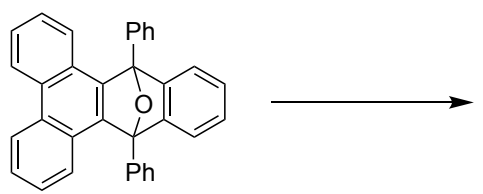

5 aa

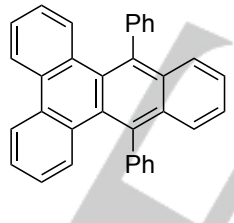

$6 a$
$\mathrm{TiCl}_{3}$ (15 equiv), $n$-BuLi (30 equiv)

$92 \%$ $\mathrm{Et}_{2} \mathrm{O}, \mathrm{RT}, 4 \mathrm{~h}$

$\mathrm{Cp}_{2} \mathrm{TiCl}_{2}$ (5 equiv), $n$-BuLi (10 equiv) $\quad 90 \%$ THF, RT, 1 h

$\mathrm{TiCl}_{4}$ (15 equiv), $\mathrm{Zn}$ (30 equiv) THF, RT, 12 h

Scheme 4. Reductive Aromatisation of 5 Under Basic Conditions $\left({ }^{1} \mathrm{H}\right.$ NMR yield based on an internal standard $\mathrm{CH}_{2} \mathrm{Br}_{2}$ ).

Next, reductive aromatisation under acidic conditions was examined with commercially available tin(II) chloride (Table 3). Using $\mathrm{SnCl}_{2}$ (10 equiv)/ $\mathrm{HCl}$ (20 equiv) afforded 6aa in $49 \%$ yield (Entry 1); however, decreasing the amounts of reagents raised the yield to $81 \%$ (Entry 2 ). The $p$-methoxy-bearing substrate $\mathbf{5 a b}$ afforded $\mathbf{6 a b}$ in $52 \%$ yield along with the migration product $\mathbf{7 a b}$ in $45 \%$ yield (Entry 3 ). As shown in Scheme 5 , the protonation of $5 \mathbf{a b}$ generated the carbocation intermediate $\mathbf{8} \mathbf{a b}$. Thus, it was rationalized that the use of a group, such as a $p$-methoxyphenyl group, that is more nucleophilic than the phenyl group, caused 1,4-migration and led to the formation of $7 \mathbf{a b}$ (Path a).

Nucleophilic components, such as alcohols and the counter anions of acids, also affected product selectivity (6ab/7ab). The use of a methanol solution of $\mathrm{HCl}$ increased the selectivity to afford $\mathbf{6 a b}$ in $76 \%$ yield and $7 \mathbf{a b}$ in $11 \%$ yield (Entry 4 , Table 3 ). In contrast, using an ether solution of $\mathrm{HCl}$ decreased product selectivity to afford $\mathbf{6 a b}$ in $37 \%$ yield and $\mathbf{7 a b}$ in $57 \%$ yield (Entry $5)$. The type of counter anions for the acid also decisively affected product selectivity; this could be best seen in the cases of $\mathrm{HBr}$ and $\mathrm{HI}$. Whereas $\mathrm{HBr}$ afforded $6 \mathrm{ab}$ and $7 \mathrm{ab}$ in $98 \%$ and

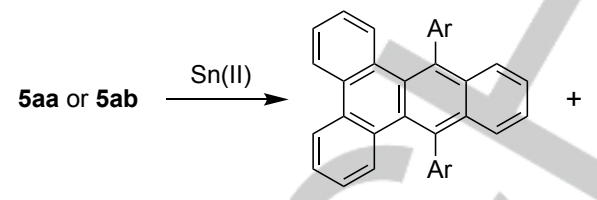

6aa, $\mathrm{Ar}=\mathrm{Ph}$

6ab, $\mathrm{Ar}=\mathrm{C}_{6} \mathrm{H}_{4} p-\mathrm{OMe}$

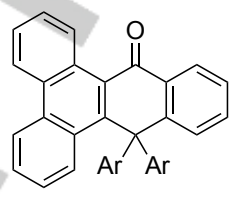

7aa, $\mathrm{Ar}=\mathrm{Ph}$

$7 \mathrm{ab}, \mathrm{Ar}=\mathrm{C}_{6} \mathrm{H}_{4} p-\mathrm{OMe}$
Table 3. Reductive Aromatisation of $\mathbf{5}$ Under Acidic Conditions.

\begin{tabular}{|c|c|c|c|c|}
\hline \multirow{2}{*}{ Entry } & \multirow{2}{*}{5} & \multirow{2}{*}{ Reagents and Conditions } & \multicolumn{2}{|c|}{ Yield [\%] ${ }^{[a]}$} \\
\hline & & & 6 & 7 \\
\hline 1 & $5 a a$ & $\begin{array}{l}\mathrm{SnCl}_{2} \text { (10 equiv), } \mathrm{HCl} \text { ( } 20 \text { equiv) } \\
\mathrm{Et}_{2} \mathrm{O}, \mathrm{RT} \text {, overnight }\end{array}$ & 49, 6аa & - \\
\hline 2 & 5 aa & $\begin{array}{l}\mathrm{SnCl}_{2} \text { (5 equiv), } \mathrm{HCl} \text { (10 equiv) } \\
\mathrm{THF} \text {, reflux, } 9 \mathrm{~h}\end{array}$ & $(81), 6 a a$ & - \\
\hline 3 & $5 a b$ & $\begin{array}{l}\mathrm{SnCl}_{2} \text { ( } 5 \text { equiv), } \mathrm{HCl} \text { (10 equiv) } \\
\mathrm{THF}, 60^{\circ} \mathrm{C}, 5 \mathrm{~h}\end{array}$ & $(52), 6 a b$ & (45), 7ab \\
\hline 4 & $5 a b$ & $\begin{array}{l}\mathrm{SnCl}_{2} \text { (5 equiv), } \mathrm{HCl} \text { (10 equiv in } \\
\mathrm{MeOH}), \mathrm{THF}, 60^{\circ} \mathrm{C}, 5 \mathrm{~h}\end{array}$ & $76,6 a b$ & $11,7 a b$ \\
\hline 5 & $5 a b$ & $\begin{array}{l}\mathrm{SnCl}_{2} \text { ( } 5 \text { equiv), } \mathrm{HCl} \text { ( } 10 \text { equiv } \\
\text { in } \mathrm{E}_{2} \mathrm{O} \text { ), THF, } 60^{\circ} \mathrm{C}, 5 \mathrm{~h}\end{array}$ & $37,6 a b$ & $57,7 a b$ \\
\hline 6 & $5 a b$ & $\begin{array}{l}\mathrm{SnCl}_{2} \text { (5 equiv), } \mathrm{HBr}(10 \text { equiv) } \\
\mathrm{THF}, 60^{\circ} \mathrm{C}, 5 \mathrm{~h}\end{array}$ & $(98), 6 a b$ & $2,7 a b$ \\
\hline 7 & $5 a b$ & $\begin{array}{l}\mathrm{SnCl}_{2} \text { ( } 5 \text { equiv), } \mathrm{HI} \text { ( } 10 \text { equiv) } \\
\mathrm{THF}, 60^{\circ} \mathrm{C}, 5 \mathrm{~h}\end{array}$ & $97,6 \mathbf{a b}$ & - \\
\hline
\end{tabular}

[a] ${ }^{1} \mathrm{H}$ NMR yield based on an internal standard $\mathrm{CH}_{2} \mathrm{Br}_{2}$ (isolated yield in parentheses).

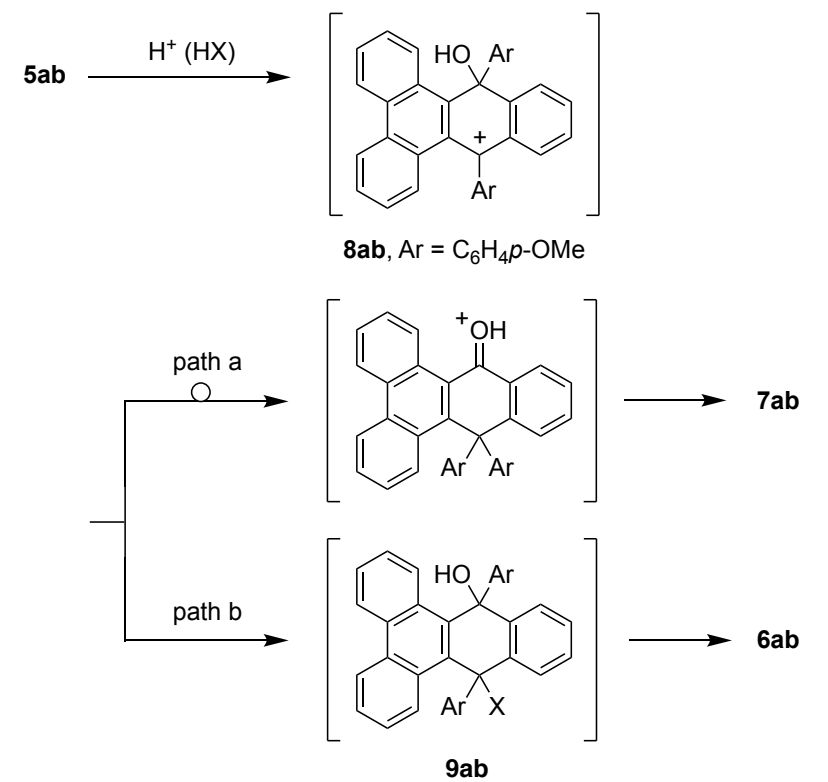

Scheme 5. A Plausible Mechanism for the Formation of Benzotriphenylene $6 \mathrm{ab}$ and Ketone $7 \mathrm{ab}$ 
$2 \%$ yields, respectively (Entry 6), $\mathrm{HI}$ afforded $\mathbf{6 a b}$ as the sole product $(97 \%$ yield, Entry 7$)$. The effect of nucleophilic components (methanol in Entry 4, a bromide ion in Entry 6 and an iodide ion in Entry 7) is rationalised through their attack on the carbocation intermediate $\mathbf{8} \mathbf{a b}$, which suppresses rearrangement to $7 \mathrm{ab}$ (Path a, Scheme 5). Thus, the generation of intermediate $\mathbf{9 a b}$ is promoted and, ultimately, the formation of the desired benzotriphenylene $\mathbf{6 a b}$ (Path b).

Using the optimised conditions, various benzotriphenylene analogues were synthesised (Table 4). The Diels-Alder adducts, 5aa-af, which had aryl groups with a functionality and thienyl groups were successfully aromatised using the aforementioned

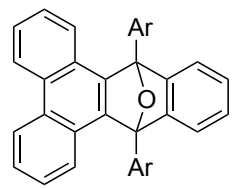

5

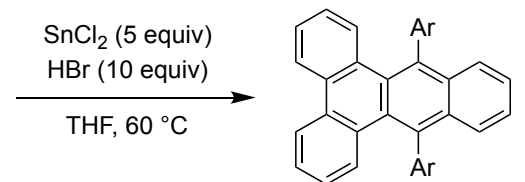

6
Table 4. Synthesis of Benzotriphenylenes 6 (1).

\begin{tabular}{llllll}
\hline Entry & $\mathrm{Ar}$ & $\mathbf{5}$ & $t[\mathrm{~h}]$ & $\mathbf{6}$ & Yield [\%] \\
\hline $1^{[\mathrm{ac}]}$ & $\mathrm{Ph}$ & $\mathbf{5 a a}$ & 10 & $\mathbf{6 a a}$ & 93 \\
$2^{[\mathrm{b}]}$ & $\mathrm{C}_{6} \mathrm{H}_{4} p-\mathrm{OMe}$ & $\mathbf{5 a b}$ & 5 & $\mathbf{6 a b}$ & 98 \\
3 & $\mathrm{C}_{6} \mathrm{H}_{4} p-n-\mathrm{Hex}$ & $\mathbf{5 a c}$ & 3 & $\mathbf{6 a c}$ & 98 \\
4 & $\mathrm{C}_{6} \mathrm{H}_{4} p-t-\mathrm{Bu}$ & $\mathbf{5 a d}$ & 12 & $\mathbf{6 a d}$ & 99 \\
5 & $\mathrm{C}_{6} \mathrm{H}_{4} p-\mathrm{F}$ & $\mathbf{5 a e}$ & 6 & $\mathbf{6 a e}$ & 86 \\
$6^{[\mathrm{cc}]}$ & $2-\mathrm{Thienyl}$ & $\mathbf{5 a f}$ & 9 & $\mathbf{6 a f}$ & 62 \\
\hline
\end{tabular}

[a] $\mathrm{SnCl}_{2}$ (15 equiv) and $\mathrm{HBr}$ (30 equiv). [b] Table 3, Entry 6. [c] $\mathrm{SnCl}_{2}$ (5 equiv) and $\mathrm{HCl}$ (10 equiv).<smiles>c1ccc(-c2cc3ccccc3c3c2C2(c4ccccc4)OC3(c3ccccc3)c3ccccc32)cc1</smiles>

5 ba<smiles></smiles>

$5 \mathrm{ca}$

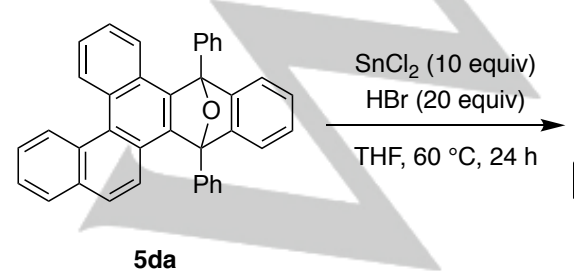

$5 \mathrm{da}$

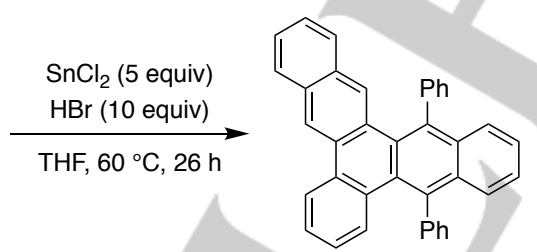

$6 \mathrm{ba}, 65 \%$

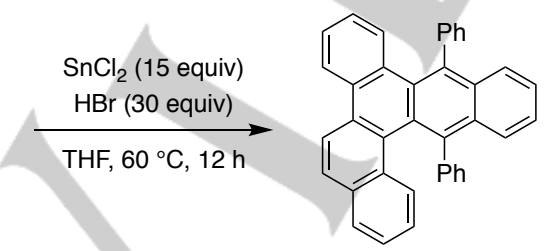

$6 \mathrm{ca}, 87 \%$

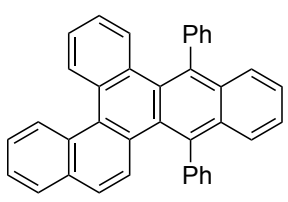

$6 \mathrm{da}, 86 \%$ acidic conditions to afford the benzotriphenylenes 6aa-af in $62 \%-99 \%$ yields. The cycloadducts $5 \mathrm{ba}, 5 \mathrm{ca}$ and $5 \mathrm{da}$, which possessed a tetraphene, a chrysene and a helicene substructure also gave $\mathbf{6 b a}, \mathbf{6 c a}$ and $\mathbf{6 d a}$ in $65 \%, 87 \%$ and $86 \%$ yields, respectively (Scheme 6 ). Thus, the generation of $\pi$ extended arynes based on domino ring assembly of 1,1difluoroallenes has facilitated systematic entry to benzotriphenylenes with structural diversity.

Intramolecular Ary-Aryl Coupling of Benzotriphenylenes 6. Dehydrogenative coupling of the aromatic compounds (the Scholl reaction) is a powerful method for expanding $\pi$-systems. Since the synthesised diaryltriphenylenes 6 were structurally suitable for the Scholl reaction, we investigated the $\pi$ extension of 6 to facilitate the synthesis of 'half HBCs' (hexabenzocoronenes). Thus, the triphenylene 6aa was treated with excess iron(III) chloride in 1,2-dichloroethane-nitromethane $(5: 1)$ at $0^{\circ} \mathrm{C}$. The desired product 10aa ('half $\mathrm{HBC}$ ') was obtained in $84 \%$ yield (Scheme 7 ). Primary and tertiary alkylbearing $6 \mathbf{a c}$ and $6 \mathrm{ad}$ underwent similar dehydrogenative coupling to give $10 \mathrm{ac}$ and $10 \mathrm{ad}$ in $98 \%$ and $94 \%$ yields, respectively. ${ }^{[22]}$

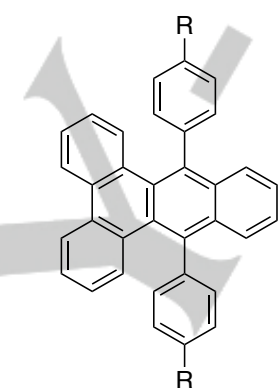

6aa $(\mathrm{R}=\mathrm{H})$

6ac $(\mathrm{R}=n-\mathrm{Hex})$

Gad $(\mathrm{R}=t-\mathrm{Bu})$

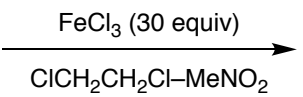

$(5: 1)$

Scheme 7. Synthesis of 'Half HBCs' 10

\section{Conclusion}

Using ortho-fluoro(halo)arenes (such as phenanthrenes, tetraphenes and chrysenes) and fluorohelicenes, benzotriphenylenes were synthesised via $\pi$-extended aryne intermediates. These aryne precursors were prepared through domino ring assembly of 1,1-difluoroallenes bearing a cyclopentene moiety and an aryl group; this reaction was initiated on treatment with the $\operatorname{lnBr}_{3}$ catalyst in the presence or absence of NBS or NIS. Metalation ( $n$-BuLi or $\mathrm{Me}_{2} \mathrm{TMPZnLi}$ ) of the precursors and the subsequent elimination of a fluoride ion generated the corresponding arynes. This is an unprecedented means for the systematic generation of $\pi$-extended arynes and may prove beneficial in accessing synthetic routes to higherorder PAHs. Diels-Alder reactions with isobenzofurans afforded cycloadducts whose reductive aromatisation in an $\mathrm{SnCl}_{2} / \mathrm{HBr}$ system furnished the fully aromatised benzotriphenylene analogues. In addition, further dehydrogenative aryl-aryl coupling (the Scholl reaction) provided a facile entry to "half HBC' analogues.

Scheme 6. Synthesis of Benzotriphenylenes 6 (2). 


\section{Experimental Section}

THF, diethyl ether and DMF were dried by passing through a column of activated alumina followed by a column of Q-5 scavenger (Engelhard) 1,2-Dichloroethane and nitromethane were distilled from $\mathrm{CaH}_{2}$ and stored under MS 4A. Me $2 \mathrm{Zn}$ (a heptane solution), $\mathrm{TiCl}_{4}, \mathrm{SnCl}_{2}$ and $\mathrm{FeCl}_{3}$ were purchased from Merck $\mathrm{KGaA}$ and used as received. $\mathrm{Cp}_{2} \mathrm{TiCl}_{2}$ and conc. $\mathrm{HBr}$ were purchased from TOKYO CHEMICAL INDUSTRY CO., LTD and used as received. $\mathrm{TiCl}_{3}$ and conc. $\mathrm{HCl}$ were purchased from Kishida Chemical Co., Ltd. and used as received.

Column chromatography was conducted on silica gel (Silica Gel 60 $\mathrm{N}$, Kanto Chemical Co., Inc. for column chromatography). Purification was also performed by preparative HPLC (GPC), using a JAI LC-908 instrument (Jaigel-2 $\mathrm{H}, \mathrm{CHCl}_{3}$ ).

IR spectra were recorded on a Horiba FT-300S spectrometer by the attenuated total reflectance (ATR method). NMR spectra were recorded on Bruker Avance 500 or Jeol JNM ECS-400 spectrometers in $\mathrm{CDCl}_{3}$ at 500 or $400 \mathrm{MHz}\left({ }^{1} \mathrm{H} \mathrm{NMR}\right)$, at 126 or $101 \mathrm{MHz}\left({ }^{13} \mathrm{C} \mathrm{NMR}\right)$, and at 470 or $376 \mathrm{MHz}\left({ }^{19} \mathrm{~F}\right.$ NMR). Chemical shifts were given in $\mathrm{ppm}$ relative to internal Me $4 \mathrm{Si}$ (for ${ }^{1} \mathrm{H}$ NMR: $\delta=0.00$ ), $\mathrm{CDCl}_{3}$ (for ${ }^{13} \mathrm{C} \mathrm{NMR}: \delta=77.0$ ) and $\mathrm{C}_{6} \mathrm{~F}_{6}$ (for ${ }^{19} \mathrm{~F}$ NMR: $\delta=0.0 ; \mathrm{C}_{6} \mathrm{~F}_{6}$ exhibits a ${ }^{19} \mathrm{~F}$ NMR signal at $-162.9 \mathrm{ppm}$ vs. $\mathrm{CFCl}_{3}$ ). High-resolution mass spectroscopy (HRMS) was conducted with Jeol JMS-T100GCV (EI/TOF) and Jeol JMS-T100CS (ESI $/$ TOF or $\mathrm{APCl}^{+} / \mathrm{TOF}$ ) spectrometers. Elemental analyses (EA) were performed with a Yanako MT-3 CHN Corder apparatus.

Isobenzofurans 4 were prepared by the reported method. ${ }^{[19 a]}$ Preparation and spectral data of ortho-fluoro(halo)phenanthrenes $(3 \mathrm{aBr}$ and 3al) were described in the previous paper.[11a] Orthofluoro(halo)tetraphenes $(\mathbf{3 b B r}$ and $3 \mathbf{b l}$ ) and ortho-fluoro(halo)chrysenes $(3 \mathrm{cBr}$ and $3 \mathrm{cl})$ were prepared by the same method. Preparation and spectral data of fluorohelicene $\mathbf{2} \mathbf{d}$ were described in the previous paper. [11a]

6-Bromo-5-fluorobenzo[a]anthracene 3bBr: ${ }^{1} \mathrm{H}$ NMR $\left(500 \mathrm{MHz}, \mathrm{CDCl}_{3}\right): \delta$ $=7.53-7.60(\mathrm{~m}, 2 \mathrm{H}), 7.64(\mathrm{dd}, J=7.5,7.5 \mathrm{~Hz}, 1 \mathrm{H}), 7.71$ (ddd, $J=7.5$ 7.5, $1.3 \mathrm{~Hz}, 1 \mathrm{H}), 8.01-8.06(\mathrm{~m}, 2 \mathrm{H}), 8.07(\mathrm{dd}, J=8.0,0.5 \mathrm{~Hz}, 1 \mathrm{H}), 8.67$ (s, $1 \mathrm{H}), 8.68(\mathrm{~d}, J=7.5 \mathrm{~Hz}, 1 \mathrm{H}), 8.97(\mathrm{~s}, 1 \mathrm{H}) ;{ }^{13} \mathrm{C} \mathrm{NMR}(126 \mathrm{MHz}$ $\left.\mathrm{CDCl}_{3}\right): \delta=103.9\left(\mathrm{~d}, J_{\mathrm{CF}}=21 \mathrm{~Hz}\right), 121.2\left(\mathrm{~d}, J_{\mathrm{CF}}=6 \mathrm{~Hz}\right), 121.8\left(\mathrm{~d}, J_{\mathrm{CF}}=\right.$ $1 \mathrm{~Hz}), 122.8\left(\mathrm{~d}, J_{\mathrm{CF}}=3 \mathrm{~Hz}\right), 124.1\left(\mathrm{~d}, J_{\mathrm{CF}}=21 \mathrm{~Hz}\right), 126.1\left(\mathrm{~d}, J_{\mathrm{CF}}=8 \mathrm{~Hz}\right)$, $126.2,126.4,126.5,127.5,127.8,128.0,128.0,128.2,130.7\left(d, J_{C F}=6\right.$ $\mathrm{Hz}), 131.2\left(\mathrm{~d}, J_{\mathrm{CF}}=1 \mathrm{~Hz}\right), 132.2,153.9\left(\mathrm{~d}, J_{\mathrm{CF}}=252 \mathrm{~Hz}\right) ;{ }^{19} \mathrm{~F}$ NMR $(470$ $\mathrm{MHz}, \mathrm{CDCl}_{3}$ ): $\delta=50.2$ (s); IR (neat): $v^{\sim}=2960,1358,1219,876,771$ $744 \mathrm{~cm}^{-1}$; HRMS (El): calcd. for $\mathrm{C}_{18} \mathrm{H}_{10} \mathrm{BrF}[\mathrm{M}]^{+}$: 323.9950; found 323.9951 .

5-Fluoro-6-iodobenzo[a]anthracene $3 \mathrm{bl:}{ }^{1} \mathrm{H}$ NMR $\left(500 \mathrm{MHz}, \mathrm{CDCl}_{3}\right): \delta=$ 7.57-7.66 (m, 2H), 7.68 (dd, $J=7.6,7.6 \mathrm{~Hz}, 1 \mathrm{H}), 7.78$ (dd, $J=7.6,7.6$ $\mathrm{Hz}, 1 \mathrm{H}), 8.09-8.14(\mathrm{~m}, 3 \mathrm{H}), 8.69(\mathrm{~s}, 1 \mathrm{H}), 8.79(\mathrm{~d}, J=8.4 \mathrm{~Hz}, 1 \mathrm{H}), 9.06(\mathrm{~s}$ $1 \mathrm{H}) ;{ }^{13} \mathrm{C}$ NMR (126 MHz, CDCl$): \delta=81.4\left(\mathrm{~d}, \mathrm{~J}_{\mathrm{CF}}=26 \mathrm{~Hz}\right), 121.5$ (d, JCF $=6 \mathrm{~Hz}), 122.0\left(\mathrm{~d}, J_{\mathrm{CF}}=1 \mathrm{~Hz}\right), 123.0\left(\mathrm{~d}, J_{\mathrm{CF}}=4 \mathrm{~Hz}\right), 124.0\left(\mathrm{~d}, J_{\mathrm{CF}}=22\right.$ $\mathrm{Hz}), 129.9\left(\mathrm{~d}, J_{\mathrm{CF}}=4 \mathrm{~Hz}\right), 131.2\left(\mathrm{~d}, J_{\mathrm{CF}}=8 \mathrm{~Hz}\right), 131.6\left(\mathrm{~d}, J_{\mathrm{CF}}=2 \mathrm{~Hz}\right)$ $131.7\left(\mathrm{~d}, J_{\mathrm{CF}}=6 \mathrm{~Hz}\right), 157.5\left(\mathrm{~d}, J_{\mathrm{CF}}=250 \mathrm{~Hz}\right), 126.3,126.5,126.6,127.5$, 127.8, 128.0, 128.6, 132.7; ${ }^{19} \mathrm{~F}$ NMR (470 MHz, $\left.\mathrm{CDCl}_{3}\right): \delta=68.9$ (s). IR (neat): $v^{\sim}=3055,1616,1495,1356,876,771 \mathrm{~cm}^{-1}$; Anal. calcd. for $\mathrm{C}_{18} \mathrm{H}_{10} \mathrm{FI}: \mathrm{C}, 58.09 ; \mathrm{H}, 2.71$; found: $\mathrm{C}, 57.67 ; \mathrm{H}, 2.55$.

6-Bromo-5-fluorochrysene $3 \mathrm{cBr}:{ }^{1} \mathrm{H}$ NMR $\left(500 \mathrm{MHz}, \mathrm{CDCl}_{3}\right): \delta=7.62-7.73$ (m, 4H), 7.96 (dd, $J=8.0,1.5 \mathrm{~Hz}, 1 \mathrm{H}), 8.00(\mathrm{~d}, J=9.0 \mathrm{~Hz}, 1 \mathrm{H}), 8.37$ (dd $J=8.5,1.0 \mathrm{~Hz}, 1 \mathrm{H}), 8.60(\mathrm{dd}, J=9.5,2.5 \mathrm{~Hz}, 1 \mathrm{H}), 8.68(\mathrm{~d}, J=8.0 \mathrm{~Hz}$, $1 \mathrm{H}), 9.13$ (br d, $J=8.5 \mathrm{~Hz}, 1 \mathrm{H}) ;{ }^{13} \mathrm{C} \mathrm{NMR}\left(126 \mathrm{MHz} \mathrm{CDCl}_{3}\right): \delta=107.3(\mathrm{~d}$ $\left.J_{\mathrm{CF}}=19 \mathrm{~Hz}\right), 119.6\left(\mathrm{~d}, J_{\mathrm{CF}}=13 \mathrm{~Hz}\right), 120.5\left(\mathrm{~d}, J_{\mathrm{CF}}=3 \mathrm{~Hz}\right), 123.3\left(\mathrm{~d}, J_{\mathrm{CF}}=\right.$ $2 \mathrm{~Hz}), 126.4\left(\mathrm{~d}, J_{\mathrm{CF}}=2 \mathrm{~Hz}\right), 126.9\left(\mathrm{~d}, J_{\mathrm{CF}}=2 \mathrm{~Hz}\right), 127.0\left(\mathrm{~d}, J_{\mathrm{CF}}=7 \mathrm{~Hz}\right)$ $127.5\left(\mathrm{~d}, J_{\mathrm{CF}}=2 \mathrm{~Hz}\right), 127.5\left(\mathrm{~d}, J_{\mathrm{CF}}=28 \mathrm{~Hz}\right), 127.96,128.02,128.1(\mathrm{~d}$ $\left.J_{\mathrm{CF}}=6 \mathrm{~Hz}\right), 128.5,129.4,130.1\left(\mathrm{~d}, J_{\mathrm{CF}}=6 \mathrm{~Hz}\right), 130.5\left(\mathrm{~d}, J_{\mathrm{CF}}=3 \mathrm{~Hz}\right)$ $132.7,156.1\left(\mathrm{~d}, J_{\mathrm{CF}}=253 \mathrm{~Hz}\right) ;{ }^{19} \mathrm{~F}$ NMR $\left(470 \mathrm{MHz}, \mathrm{CDCl}_{3}\right): \delta=63.5$ (s) IR (neat): $v \quad 3051,1589,1431,1238,912,746 \mathrm{~cm}^{-1}$; HRMS (EI): calcd for $\mathrm{C}_{18} \mathrm{H}_{10} \mathrm{BrF}[\mathrm{M}]^{+}:$323.9950; found: 323.9946 .

5-Fluoro-6-iodochrysene 3cl: ${ }^{1} \mathrm{H}$ NMR $\left(500 \mathrm{MHz}, \mathrm{CDCl}_{3}\right): \delta=7.64-7.77(\mathrm{~m}$ $4 \mathrm{H}), 7.99(\mathrm{~d}, J=7.9 \mathrm{~Hz}, 1 \mathrm{H}), 8.06(\mathrm{~d}, J=9.1 \mathrm{~Hz}, 1 \mathrm{H}), 8.33(\mathrm{dd}, J=7.9$
$1.6 \mathrm{~Hz}, 1 \mathrm{H}), 8.67-8.72(\mathrm{~m}, 2 \mathrm{H}), 9.17(\mathrm{~d}, J=8.6 \mathrm{~Hz}, 1 \mathrm{H}) ;{ }^{13} \mathrm{C}$ NMR $(126$ $\mathrm{MHz}_{\mathrm{CDCl}}$ ): $\delta=85.3$ (d, $\left.J=29 \mathrm{~Hz}\right), 119.5(\mathrm{~d}, J=15 \mathrm{~Hz}), 120.7(\mathrm{~d}, J=3$ $\mathrm{Hz}$ ), 123.5 (d, $J=2 \mathrm{~Hz}$ ), 126.5 (d, $J=3 \mathrm{~Hz}$ ), 127.0 (d, $J=2 \mathrm{~Hz}$ ), 127.6 (d, $J=3 \mathrm{~Hz}), 128.07(\mathrm{~d}, J=3 \mathrm{~Hz}), 128.09(\mathrm{~d}, J=10 \mathrm{~Hz}), 128.5(\mathrm{~d}, J=8 \mathrm{~Hz})$, $131.3(\mathrm{~d}, J=6 \mathrm{~Hz}), 132.2(\mathrm{~d}, J=6 \mathrm{~Hz}), 132.7(\mathrm{~d}, J=5 \mathrm{~Hz}), 158.9$ (d, $J=$ $251 \mathrm{~Hz}), 127.7,127.9,129.8,132.8 ;{ }^{19} \mathrm{~F}$ NMR $\left(470 \mathrm{MHz}, \mathrm{CDCl}_{3}\right): \delta=$ 83.4 (s); IR (neat): $v^{\sim} 3057,1581,1427,1238,816,756 \mathrm{~cm}^{-1}$; Anal. calcd. for $\mathrm{C}_{18} \mathrm{H}_{10} \mathrm{FI}$ : C, 58.09; $\mathrm{H}, 2.71$; found: C, 57.84; $\mathrm{H}, 2.72$.

Generation and Diels-Alder reaction of arynes (from orthofluoro(halo)arenes). Synthesis of adduct $\mathbf{5 a a}$ is described as a typical procedure. To a mixed ether-THF solution $(4: 1,4 \mathrm{~mL})$ of bromo(fluoro)phenanthrene $3 \mathrm{aBr}(36 \mathrm{mg}, 0.13 \mathrm{mmol})$ and isobenzofuran 4a $(70 \mathrm{mg}, 0.26 \mathrm{mmol}$ ) was added a hexane solution of butyllithium (1.6 $\mathrm{mol} / \mathrm{L}, 0.10 \mathrm{~mL}, 0.16 \mathrm{mmol}$ ) at room temperature. The resulting solution was stirred for $2 \mathrm{~h}$. Saturated. aq. $\mathrm{NH}_{4} \mathrm{Cl}$ was added to quench the reaction and organic materials were extracted with ethyl acetate three times. The combined extracts were washed with brine and dried over anhydrous $\mathrm{Na}_{2} \mathrm{SO}_{4}$. After removal of the solvent under reduced pressure, the residue was purified by column chromatography on silica gel (hexane/ethyl acetate $20: 1$ ) to give adduct 5 aa (52 $\mathrm{mg}, 89 \%$ yield) as a colorless solid.

9,14-Dihydro-9,14-diphenyl-9,14-epoxybenzo[b]triphenylene $\quad$ 5aa: $\quad{ }^{1} \mathrm{H}$ NMR: $\delta=6.95-7.00(\mathrm{~m}, 2 \mathrm{H}), 7.32(\mathrm{dd}, J=7.5,7.5 \mathrm{~Hz}, 2 \mathrm{H}), 7.45-7.55(\mathrm{~m}$, $8 \mathrm{H}), 7.62(\mathrm{~d}, J=8.0 \mathrm{~Hz}, 2 \mathrm{H}), 7.63-7.67(\mathrm{~m}, 2 \mathrm{H}), 8.05(\mathrm{br} d, J=5.0 \mathrm{~Hz}$, $4 \mathrm{H}), 8.62(\mathrm{~d}, J=8.0 \mathrm{~Hz}, 2 \mathrm{H}) ;{ }^{13} \mathrm{C}$ NMR: $\delta=93.2,122.0,123.5,124.5$, 125.2, 126.1, 126.2, 127.2, 128.8, 129.4 130.2, 130.4, 135.1, 148.5, 151.2; IR (neat): $v^{\sim}$ 3064, 1456, 1218, 771, $752 \mathrm{~cm}^{-1}$; HRMS $\left(\mathrm{APCl}^{+}\right)$: calcd. for $\mathrm{C}_{34} \mathrm{H}_{23} \mathrm{O}[\mathrm{M}+\mathrm{H}]^{+}$: 447.1749; found: 447.1750 .

9,14-Dihydro-9,14-di(4-methoxyphenyl)-9,14-epoxybenzo[b]triphenylene 5ab: ${ }^{1} \mathrm{H}$ NMR $\left(500 \mathrm{MHz}, \mathrm{CDCl}_{3}\right): \delta=3.88(\mathrm{~s}, 6 \mathrm{H}), 6.96-6.97(\mathrm{~m}, 2 \mathrm{H})$, 7.04 (dd, $J=7.7,1.3 \mathrm{~Hz}, 4 \mathrm{H}$ ), 7.37 (ddd, $J=8.3,7.1,1.0 \mathrm{~Hz}, 2 \mathrm{H}$ ), 7.54 (ddd, $J=8.4,7.1,1.3 \mathrm{~Hz}, 2 \mathrm{H}), 7.59-7.63(\mathrm{~m}, 2 \mathrm{H}), 7.68(\mathrm{dd}, J=8.3,1.0$ $\mathrm{Hz}, 2 \mathrm{H}), 7.96(\mathrm{br} \mathrm{d}, J=6.5 \mathrm{~Hz}, 4 \mathrm{H}), 8.68(\mathrm{~d}, J=8.4 \mathrm{~Hz}, 2 \mathrm{H}) ;{ }^{13} \mathrm{C} N M R$ $\left(126 \mathrm{MHz}, \mathrm{CDCl}_{3}\right): \delta=55.4,92.6,114.1,121.9,123.5,124.5,125.1$, 126.05, 126.12, 127.2, 127.3, 130.4, 131.7 (br), 148.5, 151.5, 160.3; IR (neat): $v^{\sim}$ 2837, 1516, 1248, 1176, 904, $723 \mathrm{~cm}^{-1}$; HRMS $\left(\mathrm{APCl}^{+}\right)$: calcd. for $\mathrm{C}_{36} \mathrm{H}_{27} \mathrm{O}_{3}[\mathrm{M}+\mathrm{H}]^{+}:$507.1960; found: 507.1957 .

9,14-Di(4-hexylphenyl)-9,14-dihydro-9,14-epoxybenzo[b]triphenylene 5ac: ${ }^{1} \mathrm{H}$ NMR $\left(500 \mathrm{MHz}, \mathrm{CDCl}_{3}\right): \delta=0.88(\mathrm{t}, J=7.0 \mathrm{~Hz}, 6 \mathrm{H}), 1.25-1.39$ $(\mathrm{m}, 12 \mathrm{H}), 1.64(\mathrm{tt}, J=7.5,7.5 \mathrm{~Hz}, 2 \mathrm{H}), 1.65(\mathrm{tt}, J=7.5,7.5 \mathrm{~Hz}, 2 \mathrm{H}), 2.69$ (t, $J=7.5 \mathrm{~Hz}, 4 \mathrm{H}), 6.96-6.99(\mathrm{~m}, 2 \mathrm{H}), 7.32(\mathrm{~d}, J=8.5 \mathrm{~Hz}, 4 \mathrm{H}), 7.35$ (ddd, $J=8.3,7.1,1.1 \mathrm{~Hz}, 2 \mathrm{H}$ ), $7.53(\mathrm{ddd}, J=8.3,7.1,1.3 \mathrm{~Hz}, 2 \mathrm{H}), 7.60-7.64$ (m, 2H), $7.68(\mathrm{dd}, J=8.3,1.0 \mathrm{~Hz}, 2 \mathrm{H}), 7.94(\mathrm{br} \mathrm{d}, J=6.7 \mathrm{~Hz}, 4 \mathrm{H}), 8.67$ $(\mathrm{d}, J=8.4 \mathrm{~Hz}, 2 \mathrm{H}) ;{ }^{13} \mathrm{C}$ NMR $\left(126 \mathrm{MHz}, \mathrm{CDCl}_{3}\right): \delta=14.1,22.6,28.9$, 31.3, 31.7, 35.8, 93.0, 122.0, 123.4, 124.6, 125.1, 126.0, 126.1, 127.3, 128.8, 130.2 (br s), 130.4, 132.3, 144.2, 148.6, 151.5; IR (neat): $v^{\sim}=$ 2925, 2856, 993, 746, $723 \mathrm{~cm}^{-1}$; HRMS (APCl+): calcd. for $\mathrm{C}_{46} \mathrm{H}_{47} \mathrm{O}$ $[\mathrm{M}+\mathrm{H}]^{+}:$: 615.3627 ; found: 615.3632 .

9,14-Di(4-tert-butylphenyl)-9,14-dihydro-9,14-epoxybenzo[b]triphenylene 5ad: ${ }^{1} \mathrm{H}$ NMR $\left(500 \mathrm{MHz} \mathrm{CDCl}_{3}\right): \delta=1.36(\mathrm{~s}, 18 \mathrm{H}), 6.96-6.97(\mathrm{~m}, 2 \mathrm{H})$, 7.38 (ddd, $J=8.3,7.1,1.1 \mathrm{~Hz}, 2 \mathrm{H}), 7.48-7.56(\mathrm{~m}, 6 \mathrm{H}), 7.58-7.64(\mathrm{~m}$, 2H), $7.75(\mathrm{~d}, J=8.3 \mathrm{~Hz}, 2 \mathrm{H}), 7.95(\mathrm{br} \mathrm{d}, J=6.5 \mathrm{~Hz}, 4 \mathrm{H}), 8.68$ (d, $J=8.4$ $\mathrm{Hz}, 2 \mathrm{H}) ;{ }^{13} \mathrm{C}$ NMR $\left(126 \mathrm{MHz}, \mathrm{CDCl}_{3}\right): \delta=31.4,34.8,93.0,121.9,123.5$, $124.7,125.0,125.6,126.0,126.1,127.4,130.0$ (br s), 130.5, 132.1, 148.6, 151.6, 152.4; IR (neat): $v^{\sim}=2962,1269,906,750,723 \mathrm{~cm}^{-1}$; HRMS (APCl ${ }^{+}$): calcd. for $\mathrm{C}_{42} \mathrm{H}_{39} \mathrm{O}[\mathrm{M}+\mathrm{H}]^{+}: 559.3001$; found: 559.3000 .

9,14-Di(4-fluorophenyl)-9,14-dihydro-9,14-epoxybenzo[ $b]$ triphenylene 5ae: ${ }^{1} \mathrm{H}$ NMR $\left(500 \mathrm{MHz}, \mathrm{CDCl}_{3}\right): \delta=6.93-6.97(\mathrm{~m}, 2 \mathrm{H}), 7.20(\mathrm{dd}, \mathrm{J}=8.8$, $8.8 \mathrm{~Hz}, 4 \mathrm{H}), 7.35$ (ddd, $J=8.0,7.0,1.0 \mathrm{~Hz}, 2 \mathrm{H}), 7.50$ (ddd, $J=8.4,7.0$ $1.5 \mathrm{~Hz}, 2 \mathrm{H}), 7.55-7.61(\mathrm{~m}, 4 \mathrm{H}), 8.02(\mathrm{br} \mathrm{s}, 4 \mathrm{H}), 8.61$ (d, J = 8.4 Hz, 2H); ${ }^{13} \mathrm{C}$ NMR $\left(126 \mathrm{MHz}, \mathrm{CDCl}_{3}\right): \delta=92.5,115.8\left(\mathrm{~d}, J_{\mathrm{CF}}=22 \mathrm{~Hz}\right), 121.9$, 123.6, 124.2, 125.4, 126.2, 126.4, 127.0, 130.5, 130.9 (d, JCF $=2 \mathrm{~Hz})$, 132.2 (br), 148.1, 150.9, $163.4\left(\mathrm{~d}, \mathrm{~J}_{\mathrm{CF}}=249 \mathrm{~Hz}\right) ;{ }^{19} \mathrm{~F}$ NMR $(470 \mathrm{MHz}$, $\left.\mathrm{CDCl}_{3}\right): \delta=49.9-50.0(\mathrm{~m})$; IR (neat): $\mathrm{v}^{\sim}=1512,1227,833,750,725 \mathrm{~cm}^{-}$ 
1; HRMS (APCl+): Calcd. for $\mathrm{C}_{34} \mathrm{H}_{21} \mathrm{~F}_{2} \mathrm{O}[\mathrm{M}+\mathrm{H}]^{+}$: 483.1561; found: 483.1564

9,14-Dihydro-9,14-di(2-thienyl)-9,14-epoxybenzo[b]triphenylene 5af: ${ }^{1} \mathrm{H}$ NMR $\left(500 \mathrm{MHz}, \mathrm{CDCl}_{3}\right): \delta=7.05(\mathrm{dd}, J=9.0,4.0 \mathrm{~Hz}, 2 \mathrm{H}), 7.22-7.28(\mathrm{~m}$, 2H), 7.43 (ddd, $J=10.0,7.0,1.0 \mathrm{~Hz}, 2 \mathrm{H}$ ), 7.57 (ddd, $J=8.0,7.5,1.5 \mathrm{~Hz}$, 2H), 7.56-7.61 (m, 2H), 7.76-7.82 (m, 6H), $8.69(\mathrm{~d}, J=8.4 \mathrm{~Hz}, 2 \mathrm{H}) ;{ }^{13} \mathrm{C}$ NMR $\left(126 \mathrm{MHz}, \mathrm{CDCl}_{3}\right): \delta=88.8,121.2,123.5,124.0,125.7,126.2$ 126.4, 126.8, 127.3, 127.8, 129.7, 130.5, 138.0, 147.1, 150.8; IR (neat) $v^{\sim}=1215,771,744,723,667 \mathrm{~cm}^{-1}$; HRMS $\left(\mathrm{APCl}^{+}\right)$: calcd. for $\mathrm{C}_{30} \mathrm{H}_{19} \mathrm{OS}{ }_{2}$ $[\mathrm{M}+\mathrm{H}]^{+}:$: 459.0877; found: 459.0876

5,16-Dihydro-5,16-diphenyl-5,16-epoxybenzo[h]pentaphene $\quad$ 5ba: $\quad{ }^{1} \mathrm{H}$ NMR ( $500 \mathrm{MHz}, \mathrm{CDCl}_{3}$ ): $\delta=6.95-7.01(\mathrm{~m}, 2 \mathrm{H}), 7.36$ (ddd, $J=8.5,7.0$ $1.0 \mathrm{~Hz}, 1 \mathrm{H}$ ), 7.40 (ddd, $J=8.0,6.5,1.3 \mathrm{~Hz}, 1 \mathrm{H}$ ), 7.45 (ddd, $J=8.0,6.5$ $1.4 \mathrm{~Hz}, 1 \mathrm{H}), 7.48-7.57(\mathrm{~m}, 7 \mathrm{H}), 7.60(\mathrm{dd}, J=8.3,0.8 \mathrm{~Hz}, 1 \mathrm{H}), 7.64(\mathrm{~d}, J$ $=8.5 \mathrm{~Hz}, 1 \mathrm{H}), 7.66-7.69(\mathrm{~m}, 1 \mathrm{H}), 7.71-7.75(\mathrm{~m}, 1 \mathrm{H}), 8.01(\mathrm{~d}, J=8.0 \mathrm{~Hz}$ $1 \mathrm{H}), 8.06(\mathrm{~s}, 1 \mathrm{H}), 8.08(\mathrm{~d}, J=6.0 \mathrm{~Hz}, 2 \mathrm{H}), 8.11(\mathrm{br} \mathrm{s}, 2 \mathrm{H}), 8.81(\mathrm{~d}, J=$ $8.0 \mathrm{~Hz}, 1 \mathrm{H}), 9.14(\mathrm{~s}, 1 \mathrm{H}) ;{ }^{13} \mathrm{C} \mathrm{NMR}\left(126 \mathrm{MHz}, \mathrm{CDCl}_{3}\right): \delta=93.3,121.9$, $122.0,122.5,123.1,123.7,124.7,125.16,125.22,125.7,125.9,126.49$ $126.55,127.5,128.1,128.3,128.77,128.79,129.1,129.39,129.45$, 130.3 (br s), 130.9, 131.2, 131.3, 135.0, 135.1, 148.8, 148.9, 151.07 151.15; IR (neat): $v^{\sim}=3014,1215,746,698,667 \mathrm{~cm}^{-1}$; HRMS $\left.(\mathrm{APCl})^{+}\right)$: calcd. for $\mathrm{C}_{38} \mathrm{H}_{25} \mathrm{O}[\mathrm{M}+\mathrm{H}]^{+}$: 497.1905; found: 497.1920 .

11,16-Dihydro-11,16-diphenyl-11,16-epoxynaphtho[2,3-g]chrysene $\mathbf{5} \mathbf{c a}$ ${ }^{1} \mathrm{H}$ NMR $\left(500 \mathrm{MHz}, \mathrm{CDCl}_{3},-40^{\circ} \mathrm{C}\right): \delta=6.95(\mathrm{dd}, J=7.7,7.7 \mathrm{~Hz}, 1 \mathrm{H})$, 7.02 (dd, $J=7.7,7.7 \mathrm{~Hz}, 1 \mathrm{H}$ ), 7.10 (d, $J=7.8 \mathrm{~Hz}, 1 \mathrm{H}$ ), 7.21 (dd, $J=7.2$ $\mathrm{Hz}, 1 \mathrm{H}), 7.23(\mathrm{~d}, J=7.2 \mathrm{~Hz}, 1 \mathrm{H}), 7.29(\mathrm{dd}, J=7.4,7.4 \mathrm{~Hz}, 1 \mathrm{H}), 7.36-$ $7.45(\mathrm{~m}, 3 \mathrm{H}), 7.48-7.68(\mathrm{~m}, 4 \mathrm{H}), 7.51(\mathrm{dd}, J=7.4,7.4 \mathrm{~Hz}, 1 \mathrm{H}), 7.56(\mathrm{dd}$ $J=7.7,7.7 \mathrm{~Hz}, 1 \mathrm{H}), 7.87(\mathrm{~d}, J=7.9 \mathrm{~Hz}, 1 \mathrm{H}), 7.89-7.96(\mathrm{~m}, 3 \mathrm{H}), 8.03(\mathrm{~d}$ $J=7.1 \mathrm{~Hz}, 1 \mathrm{H}), 8.24(\mathrm{~d}, J=7.7 \mathrm{~Hz}, 1 \mathrm{H}), 8.36(\mathrm{br} \mathrm{s}, 1 \mathrm{H}), 8.72(\mathrm{~d}, J=9.1$ $\mathrm{Hz}, 1 \mathrm{H}), 8.76(\mathrm{~d}, J=8.6 \mathrm{~Hz}, 1 \mathrm{H}) ;{ }^{13} \mathrm{C}$ NMR $\left(126 \mathrm{MHz}, \mathrm{CDCl}_{3},-40{ }^{\circ} \mathrm{C}\right): \delta$ $=91.9,94.7,121.2,122.4,122.8,123.2,123.8,124.4,125.2,125.4$ $125.5,125.6,125.9,126.0,126.2,126.9,126.97,127.04,127.4,127.7$, 128.0 (br), 128.56, 128.59, 128.62 (br), 128.7, 128.8 (br), 129.3, 129.5 129.6, 129.8, 132.0, 134.0, 135.0, 147.6, 147.9, 149.8, 151.2; IR (neat) $v^{\sim}=3055,1454,1300,906,727,698 \mathrm{~cm}^{-1}$; HRMS $\left(\mathrm{APCl}^{+}\right)$: calcd. for $\mathrm{C}_{38} \mathrm{H}_{25} \mathrm{O}[\mathrm{M}+\mathrm{H}]^{+}:$497.1905; found: 497.1903 .

Generation and Diels-Alder reaction of arynes (from fluorohelicenes). Synthesis of adduct $\mathbf{5 d a}$ is described as a typical procedure. To a THF solution $(2 \mathrm{~mL})$ of fluorohelicene $2 \mathbf{d}(40 \mathrm{mg}, 0.16$ $\mathrm{mmol}$ ) and isobenzofuran $4 \mathrm{a}(87 \mathrm{mg}, 0.32 \mathrm{mmol})$ was added a THF solution of $\mathrm{Me}_{2}(\mathrm{TMP}) \mathrm{ZnLi}(0.30 \mathrm{~mol} / \mathrm{L}, 1.2 \mathrm{~mL}, 0.35 \mathrm{mmol})^{[21]}$ at $-78{ }^{\circ} \mathrm{C}$. The resulting solution was heated to reflux and stirred for $6 \mathrm{~h}$. Saturated. aq. $\mathrm{NH}_{4} \mathrm{Cl}$ was added to quench the reaction and organic materials were extracted with dichloromethane three times. The combined extracts were washed with brine and dried over anhydrous $\mathrm{Na}_{2} \mathrm{SO}_{4}$. After removal of the solvent under reduced pressure, the residue was purified by column chromatography on silica gel (hexane/ethyl acetate 20:1) to give adduct $\mathbf{5 d a}(74 \mathrm{mg}, 93 \%$ yield) as a pale yellow solid.

9,14-Dihydro-9,14-diphenyl-9,14-epoxydibenzo[b,p]chrysene $\quad \mathbf{5 d a} \quad{ }^{1} \mathrm{H}$ NMR $\left(500 \mathrm{MHz}, \mathrm{CDCl}_{3}\right): \delta=6.98-7.06(\mathrm{~m}, 2 \mathrm{H}), 7.34(\mathrm{dd}, J=7.4,7.4 \mathrm{~Hz}$, $1 \mathrm{H}), 7.44-7.60(\mathrm{~m}, 12 \mathrm{H}), 7.60-7.67(\mathrm{~m}, 2 \mathrm{H}), 7.69(\mathrm{~d}, J=6.7 \mathrm{~Hz}, 1 \mathrm{H})$, $7.74(\mathrm{~d}, J=8.2 \mathrm{~Hz}, 1 \mathrm{H}), 7.89(\mathrm{~d}, J=7.7 \mathrm{~Hz}, 1 \mathrm{H}), 8.00-8.12(\mathrm{~m}, 2 \mathrm{H}), 8.97$ (d, $J=8.3 \mathrm{~Hz}, 1 \mathrm{H}), 9.03(\mathrm{~d}, J=8.5 \mathrm{~Hz}, 1 \mathrm{H}) ;{ }^{13} \mathrm{C} \mathrm{NMR}\left(126 \mathrm{MHz}, \mathrm{CDCl}_{3}\right)$ : $\delta=93.28,93.34,122.0,122.1,122.5,123.8,125.29,125.33,125.5$, $125.8,125.9,125.99,126.04,126.3,127.6,128.2,128.3,128.76,128.80$ $128.9,129.1,129.4,129.5,130.3,130.4,130.8,132.9,134.7,134.9$, 148.0, 149.1, 151.1, 151.2; IR (neat): $v^{\sim}=2925,1454,1259,1090,1020$, 748, $698 \mathrm{~cm}^{-1}$; HRMS $\left(\mathrm{APCl}^{+}\right)$: calcd. for $\mathrm{C}_{38} \mathrm{H}_{24} \mathrm{O}[\mathrm{M}+\mathrm{H}]^{+}: 497,1900$; found: 497.1904

Reductive aromatisation of Diels-Alder adducts. Synthesis of benzotriphenylene $6 \mathbf{a a}$ is described as a typical procedure. To a THF solution $(3 \mathrm{~mL})$ of Diels-Alder adduct $5 \mathbf{a a}(28 \mathrm{mg}, 0.055 \mathrm{mmol})$ and $\mathrm{SnCl}_{2}(167 \mathrm{mg}, 0.88 \mathrm{mmol})$ was added $c . \mathrm{HBr}(0.2 \mathrm{~mL}, 1.7 \mathrm{mmol})$ at room temperature. The resulting solution was heated to $60^{\circ} \mathrm{C}$ and stirred for $10 \mathrm{~h}$. A small amount of $\mathrm{SiO}_{2}$ was added to the resulting mixture. After removal of the solvent under reduced pressure, the silica gel was charged to a small pad of $\mathrm{SiO}_{2}$ and purification by column chromatography (hexane/ethyl acetate 10:1) gave benzotriphenylene 6aa (27 mg, 93\% yield) as a colorless solid

9,14-Diphenylbenzo[b]triphenylene 6aa: ${ }^{1} \mathrm{H}$ NMR $\left(500 \mathrm{MHz}, \mathrm{CDCl}_{3}\right): \delta=$ 6.97 (ddd, $J=8.5,7.0,1.0 \mathrm{~Hz}, 2 \mathrm{H}$ ), 7.33 (ddd, $J=8.5,7.0,1.0 \mathrm{~Hz}, 2 \mathrm{H}$ ), 7.42-7.46 (m, 2H), 7.46-7.57 (m, 12H), 7.91-7.95 (m, 2H), 8.26 (dd, $J=$ 8.1, $1.0 \mathrm{~Hz}, 2 \mathrm{H}) ;{ }^{13} \mathrm{C} \mathrm{NMR}\left(126 \mathrm{MHz}, \mathrm{CDCl}_{3}\right): \delta=123.3,125.6,125.8$, $126.7,126.8,127.6,128.9,129.0,130.5,131.3,131.7,131.9,132.6$, 135.4, 141.7; IR (neat): $v^{\sim}=3062,1487,1439,744,702 \mathrm{~cm}^{-1}$; HRMS $\left(\mathrm{APCl}^{+}\right)$: calcd. for $\mathrm{C}_{34} \mathrm{H}_{23}[\mathrm{M}+\mathrm{H}]^{+}: 431.1800$; found: 431.1789 .

9,14-Di(4-methoxyphenyl)benzo[b]triphenylene 6ab: ${ }^{1} \mathrm{H}$ NMR $(500 \mathrm{MHz}$, $\mathrm{CDCl}_{3}$ ): $\delta=3.91(\mathrm{~s}, 6 \mathrm{H}), 7.00$ (ddd, $J=8.4,7.2,1.2 \mathrm{~Hz}, 2 \mathrm{H}$ ), 7.05-7.08 (m, 4H), 7.33 (ddd, $J=8.1,7.0,1.1 \mathrm{~Hz}, 2 \mathrm{H}), 7.42-7.47(\mathrm{~m}, 6 \mathrm{H}), 7.54(\mathrm{dd}$, $J=8.5,1.1 \mathrm{~Hz}, 2 \mathrm{H}), 7.96(\mathrm{br} \mathrm{d}, J=6.6 \mathrm{~Hz}, 2 \mathrm{H}), 8.25(\mathrm{dd}, J=8.5,1.1 \mathrm{~Hz}$, $2 \mathrm{H}) ;{ }^{13} \mathrm{C}$ NMR $\left(126 \mathrm{MHz}, \mathrm{CDCl}_{3}\right): \delta=55.4,123.3,125.5,125.8,126.6$, 126.7, 129.0, 130.3, 131.6, 131.9, 132.1, 133.7 (2C), 133.9, 134.8, 159.2; IR (neat): $v^{\sim}=1217,912,771,748,731 \mathrm{~cm}^{-1}$; HRMS (APCI+): calcd. for $\mathrm{C}_{36} \mathrm{H}_{27} \mathrm{O}_{2}[\mathrm{M}+\mathrm{H}]^{+}$: 491.2011; found: 491.2025 .

9,14-Di(4-hexylphenyl)benzo[b]triphenylene 6ac: ${ }^{1} \mathrm{H}$ NMR $(500 \mathrm{MHz}$ $\left.\mathrm{CDCl}_{3}\right): \delta=0.93(\mathrm{t}, J=7.1 \mathrm{~Hz}, 6 \mathrm{H}), 1.32-1.46(\mathrm{~m}, 12 \mathrm{H}), 1.73(\mathrm{tt}, J=7.7$, $7.6 \mathrm{~Hz}, 4 \mathrm{H}$ ), $2.74(\mathrm{t}, J=7.7 \mathrm{~Hz}, 4 \mathrm{H}), 6.95$ (ddd, $J=8.4,7.1,1.3 \mathrm{~Hz}, 2 \mathrm{H}$ ), 7.30-7.34 (m, 6H), 7.42-7.46 (m, 6H), $7.50(\mathrm{dd}, J=8.4,1.0 \mathrm{~Hz}, 2 \mathrm{H})$ 7.96-8.00 (m, 2H), 8.25 (dd, $J=8.4,1.2 \mathrm{~Hz}, 2 \mathrm{H}) ;{ }^{13} \mathrm{C}$ NMR $(126 \mathrm{MHz}$, $\left.\mathrm{CDCl}_{3}\right): \delta=14.1,22.7,28.9,31.4,31.8,35.8,123.2,125.5,125.6,126.6$, $126.8,128.9,129.0,130.4,131.5,131.8,131.9,132.4,135.3,138.8$, 142.3; IR (neat): $v^{\sim}=2925,2854,904,752,727 \mathrm{~cm}^{-1}$; HRMS $\left(\mathrm{APCl}+\mathrm{H}^{+}\right.$: calcd. for $\mathrm{C}_{46} \mathrm{H}_{47}[\mathrm{M}+\mathrm{H}]^{+}$: 599.3678; found: 599.3667 .

9,14-Di(4-tert-butylphenyl)benzo[b]triphenylene 6ad: ${ }^{1} \mathrm{H}$ NMR $(500 \mathrm{MHz}$, $\left.\mathrm{CDCl}_{3}\right): \delta=1.42(\mathrm{~s}, 18 \mathrm{H}), 6.93(\mathrm{dd}, J=7.7,7.7 \mathrm{~Hz}, 2 \mathrm{H}), 7.30(\mathrm{dd}, J=7.7$, $7.7 \mathrm{~Hz}, 2 \mathrm{H}), 7.39-7.48(\mathrm{~m}, 8 \mathrm{H}), 7.52(\mathrm{~d}, J=8.1 \mathrm{~Hz}, 4 \mathrm{H}), 7.99-8.02(\mathrm{~m}$, $2 \mathrm{H}), 8.23(\mathrm{~d}, \mathrm{~J}=8.0 \mathrm{~Hz}, 2 \mathrm{H}) ;{ }^{13} \mathrm{C}$ NMR $\left(126 \mathrm{MHz}, \mathrm{CDCl}_{3}\right): \delta=31.5,34.7$, $123.2,125.5,125.6,125.8,126.6,126.8,129.0,130.4,131.6,131.88$, 131.92, 132.2, 135.3, 138.6, 150.7; IR (neat): $v^{\sim}=2962,2925,912,748$, $727 \mathrm{~cm}^{-1}$; HRMS $\left(\mathrm{APCl}^{+}\right)$: calcd. for $\mathrm{C}_{42} \mathrm{H}_{39}[\mathrm{M}+\mathrm{H}]^{+}$: 543.3052; found: 543.3046

9,14-Di(4-fluorophenyl)benzo[b]triphenylene 6ae: ${ }^{1} \mathrm{H}$ NMR $(500 \mathrm{MHz}$, $\mathrm{CDCl}_{3}$ ): $\delta=7.02$ (ddd, $J=8.0,7.0,1.0 \mathrm{~Hz}, 2 \mathrm{H}$ ), 7.23 (dd, $J=8.4,8.4 \mathrm{~Hz}$, $4 \mathrm{H}$ ), 7.37 (ddd, $J=8.0,7.0,1.0 \mathrm{~Hz}, 2 \mathrm{H}), 7.44-7.54(\mathrm{~m}, 8 \mathrm{H}), 7.86-7.91$ (m, 2H), 8.27 (dd, $J=8.4,1.0 \mathrm{~Hz}, 2 \mathrm{H}) ;{ }^{13} \mathrm{C}$ NMR $\left(126 \mathrm{MHz}, \mathrm{CDCl}_{3}\right): \delta=$ $116.1\left(\mathrm{~d}, J_{\mathrm{CF}}=21 \mathrm{~Hz}\right), 123.4,125.9\left(\mathrm{~d}, \mathrm{~J}_{\mathrm{CF}}=5 \mathrm{~Hz}\right), 126.4,127.0,129.1$, $130.3,131.0,131.8,132.0,134.1,134.2,134.3,137.4\left(\mathrm{~d}, J_{\mathrm{CF}}=3 \mathrm{~Hz}\right)$, $162.5\left(\mathrm{~d}, J_{\mathrm{CF}}=248 \mathrm{~Hz}\right) ;{ }^{19} \mathrm{~F}$ NMR $\left(470 \mathrm{MHz}, \mathrm{CDCl}_{3}\right): \delta=47.4-47.5(\mathrm{~m})$; IR (neat): $v^{\sim}=1506,1223,845,750,727 \mathrm{~cm}^{-1}$; HRMS (APCl$)^{+}$): calcd. for $\mathrm{C}_{34} \mathrm{H}_{21} \mathrm{~F}_{2}[\mathrm{M}+\mathrm{H}]^{+}:$467.1611; found: 467.1618

9,14-Di(2-thienyl)benzo[ $b]$ triphenylene 6af: ${ }^{1} \mathrm{H}$ NMR $\left(500 \mathrm{MHz}, \mathrm{CDCl}_{3}\right): \delta$ $=7.09$ (ddd, $J=7.5,7.0,1.0 \mathrm{~Hz}, 2 \mathrm{H}), 7.25-7.29(\mathrm{~m}, 2 \mathrm{H}), 7.34-7.37(\mathrm{~m}$, 2H), 7.39 (ddd, $J=8.0,7.0,1.0 \mathrm{~Hz}, 2 \mathrm{H}$ ), $7.50-7.55(\mathrm{~m}, 4 \mathrm{H}), 7.70$ (dd, $J=$ 8.5, $1.0 \mathrm{~Hz}, 2 \mathrm{H}), 8.23-8.27(\mathrm{~m}, 2 \mathrm{H}), 8.27(\mathrm{dd}, J=8.5,1.0 \mathrm{~Hz}, 2 \mathrm{H}) ;{ }^{13} \mathrm{C}$ NMR $\left(126 \mathrm{MHz}, \mathrm{CDCl}_{3}\right): \delta=123.4,126.1,126.28,126.32,127.2,127.4$, 127.7, 127.8, 129.0, 130.4, 130.4, 131.1, 131.8, 132.5, 142.7; IR (neat): $v^{\sim}=2922,1259,1095,1024,798 \mathrm{~cm}^{-1}$; HRMS $\left(\mathrm{APCl}^{+}\right)$: calcd. for $\mathrm{C}_{30} \mathrm{H}_{19} \mathrm{~S}_{2}[\mathrm{M}+\mathrm{H}]^{+}:$:443.0928; found: 443.0930 .

5,16-Diphenylbenzo[ $h]$ pentaphene 6ba: ${ }^{1} \mathrm{H}$ NMR $\left(500 \mathrm{MHz}, \mathrm{CDCl}_{3}\right): \delta=$ 6.98 (ddd, $J=8.5,7.0,1.0 \mathrm{~Hz}, 1 \mathrm{H}$ ), $7.28(\mathrm{~d}, J=7.6 \mathrm{~Hz}, 1 \mathrm{H}$ ), 7.31 (ddd, $J$ $=7.6,6.5,1.1 \mathrm{~Hz}, 1 \mathrm{H}), 7.35$ (ddd, $J=7.9,6.9,1.2 \mathrm{~Hz}, 1 \mathrm{H}), 7.41$ (ddd, $J=$ 8.5, 6.7, $1.5 \mathrm{~Hz}, 1 \mathrm{H}), 7.44-7.60(\mathrm{~m}, 11 \mathrm{H}), 7.62-7.66(\mathrm{~m}, 2 \mathrm{H}), 7.90(\mathrm{~d}, 8.2$ $\mathrm{Hz}, 1 \mathrm{H}), 7.92-7.97(\mathrm{~m}, 2 \mathrm{H}), 7.98(\mathrm{~s}, 1 \mathrm{H}), 8.38(\mathrm{dd}, J=8.1,0.8 \mathrm{~Hz}, 1 \mathrm{H})$, $8.66(\mathrm{~s}, 1 \mathrm{H}) ;{ }^{13} \mathrm{C}$ NMR $\left(126 \mathrm{MHz}, \mathrm{CDCl}_{3}\right): \delta=121.5,123.9,125.5,125.67$, $125.70,126.1,126.2,126.6,126.8,126.9,127.3,127.5,127.6,128.3$, $128.9,129.1,129.2,129.3,129.6,130.7,130.7,130.9,131.66,131.69$, $131.8,132.0,132.1,132.3,132.5,132.6,135.6,135.6,141.5,141.7$; IR (neat): $v^{\sim}=3053,1489,906,737,704 \mathrm{~cm}^{-1}$; HRMS $\left(\mathrm{APCl}^{+}\right)$: calcd. for $\mathrm{C}_{38} \mathrm{H}_{25}[\mathrm{M}+\mathrm{H}]^{+}:$481.1956; found: 481.1956. 
11,16-Diphenylnaphtho[2,3-g]chrysene 6ca: ${ }^{1} \mathrm{H}$ NMR $\left(500 \mathrm{MHz}, \mathrm{CDCl}_{3}\right.$, $\left.40{ }^{\circ} \mathrm{C}\right): \delta=6.49(\mathrm{~d}, J=7.7 \mathrm{~Hz}, 1 \mathrm{H}), 6.79(\mathrm{dd}, J=7.5,7.5 \mathrm{~Hz}, 1 \mathrm{H}), 7.01$ $(\mathrm{dd}, J=7.5,7.5 \mathrm{~Hz}, 1 \mathrm{H}), 7.08(\mathrm{dd}, J=7.7,7.7 \mathrm{~Hz}, 1 \mathrm{H}), 7.10(\mathrm{dd}, J=7.7$, $7.7 \mathrm{~Hz}, 1 \mathrm{H}$ ), 7.21 (dd, $J=7.7,7.7 \mathrm{~Hz}, 1 \mathrm{H}), 7.34(\mathrm{dd}, J=7.7,7.7 \mathrm{~Hz}, 1 \mathrm{H})$ $7.41-7.65(\mathrm{~m}, 8 \mathrm{H}), 7.75(\mathrm{dd}, J=7.5,7.5 \mathrm{~Hz}, 1 \mathrm{H}), 7.83(\mathrm{~d}, J=7.5 \mathrm{~Hz}, 1 \mathrm{H})$ $7.86(\mathrm{~d}, J=8.8 \mathrm{~Hz}, 1 \mathrm{H}), 7.95(\mathrm{~d}, J=8.3 \mathrm{~Hz}, 1 \mathrm{H}), 7.99(\mathrm{dd}, J=6.5,2.7$ $\mathrm{Hz}, 1 \mathrm{H}), 8.19(\mathrm{~d}, J=7.7 \mathrm{~Hz}, 1 \mathrm{H}), 8.27(\mathrm{~d}, J=7.9 \mathrm{~Hz}, 1 \mathrm{H}), 8.38(\mathrm{~d}, J=8.8$ $\mathrm{Hz}, 1 \mathrm{H}), 8.48(\mathrm{~d}, J=8.3 \mathrm{~Hz}, 1 \mathrm{H}) ;{ }^{13} \mathrm{C} \mathrm{NMR}\left(126 \mathrm{MHz} \mathrm{CDCl}_{3},-40{ }^{\circ} \mathrm{C}\right): \delta=$ $120.1,123.3,124.9,125.0,125.4,125.5,125.9,126.47,126.55,126.63$, $126.7,126.80,126.82,127.1,127.56,127.64,127.9,127.9,128.3,128.6$, $128.7,129.0,129.2,129.5,129.5,130.0,131.1,131.3,131.4,131.81$, 131.84, 132.3, 133.0, 133.6, 134.4, 137.3, 139.8, 141.2; IR (neat): $v^{\sim}=$ 3053, 2924, 1489, 906, 729, $702 \mathrm{~cm}^{-1}$; $\mathrm{HRMS}\left(\mathrm{APCl}^{+}\right)$: calcd. for $\mathrm{C}_{38} \mathrm{H}_{25}$ $[\mathrm{M}+\mathrm{H}]^{+}:$481.1956; found: 481.1954 .

9,14-Diphenyldibenzo[b,p]chrysene 6da: ${ }^{1} \mathrm{H}$ NMR $\left(500 \mathrm{MHz}, \mathrm{CDCl}_{3}\right): \delta=$ 7.03 (ddd, $J=7.7,7.7,1,3 \mathrm{~Hz}, 1 \mathrm{H}$ ), 7.33 (ddd, $J=7.6,7.6,1.1 \mathrm{~Hz}, 1 \mathrm{H}$ ), $7.40(\mathrm{~d}, J=9.1 \mathrm{~Hz}, 1 \mathrm{H}), 7.44-7.64(\mathrm{~m}, 16 \mathrm{H}), 7.76(\mathrm{dd}, J=8.0,1.2 \mathrm{~Hz}$, $1 \mathrm{H}), 7.96-8.02(\mathrm{~m}, 2 \mathrm{H}), 8.39(\mathrm{dd}, J=8.1,1.1 \mathrm{~Hz}, 1 \mathrm{H}), 8.83(\mathrm{~d}, J=8.5 \mathrm{~Hz}$, $1 \mathrm{H}) ;{ }^{13} \mathrm{C}$ NMR $\left(126 \mathrm{MHz}, \mathrm{CDCl}_{3}\right): \delta=125.51,125.54,125.6,125.7,125.8$, $125.9,126.3,126.7,126.8,127.6,127.8,129.5,129.6,129.9,130.0$, $130.7,131.8,132.0,132.7,132.8,132.9,133.0,134.6,134.8,141.2$ 141.6; IR (neat): $v^{\sim}=3060,3022,1493,752,704 \mathrm{~cm}^{-1}$; HRMS $\left(\mathrm{APCl}^{+}\right)$: calcd. for $\mathrm{C}_{38} \mathrm{H}_{24}[\mathrm{M}+\mathrm{H}]^{+}:$481.1951; found: 481.1965 .

9,9-Di(4-methoxyphenyl)benzo[b]triphenylen-14(9H)-one $7 \mathrm{ab}:{ }^{1} \mathrm{H}$ NMR $\left(500 \mathrm{MHz}, \mathrm{CDCl}_{3}\right): \delta=3.60(\mathrm{~s}, 3 \mathrm{H}), 3.81(\mathrm{~s}, 3 \mathrm{H}), 6.55(\mathrm{~d}, J=8.9 \mathrm{~Hz}, 2 \mathrm{H})$, $6.62(\mathrm{~d}, J=7.4 \mathrm{~Hz}, 1 \mathrm{H}), 6.64$ (dd, $J=8.5,2.0 \mathrm{~Hz}, 1 \mathrm{H}), 6.69$ (dd, $J=8.5$, $2.6 \mathrm{~Hz}, 1 \mathrm{H}), 6.75$ (ddd, $J=8.0,8.0,0.9 \mathrm{~Hz}, 1 \mathrm{H}), 6.84-6.88(\mathrm{~m}, 2 \mathrm{H}), 6.99$ (ddd, $J=8.5,7.7,1.1 \mathrm{~Hz}, 1 \mathrm{H}), 7.07(\mathrm{dd}, J=8.5,2.6 \mathrm{~Hz}, 1 \mathrm{H}), 7.10(\mathrm{~d}, J=$ $8.0 \mathrm{~Hz}, 1 \mathrm{H}$ ), 7.34 (ddd, $J=8.8,7.5,1.3 \mathrm{~Hz}, 1 \mathrm{H}$ ), 7.38 (ddd, $J=8.5,6.6$, $0.9 \mathrm{~Hz}, 1 \mathrm{H}$ ), 7.43 (ddd, $J=8.5,7.5,1.0 \mathrm{~Hz}, 1 \mathrm{H}$ ), 7.47 (ddd, $J=9.0,7.7$, $1.4 \mathrm{~Hz}, 1 \mathrm{H}), 7.49$ (d, $J=8.0 \mathrm{~Hz}, 1 \mathrm{H}), 7.53(\mathrm{dd}, J=8.4,2.1 \mathrm{~Hz}, 1 \mathrm{H}), 7.61$ $(\mathrm{dd}, J=7.8,1.1 \mathrm{~Hz}, 1 \mathrm{H}), 7.80(\mathrm{dd}, J=7.8,1.0 \mathrm{~Hz}, 1 \mathrm{H}), 8.26(\mathrm{dd}, J=7.8$, $1.5 \mathrm{~Hz}, 1 \mathrm{H}) ;{ }^{13} \mathrm{C}$ NMR $\left(126 \mathrm{MHz}, \mathrm{CDCl}_{3}\right): \delta=54.9,55.2,60.4,113.3$ $113.3,113.7,114.1,123.2,125.6,126.8,127.28,127.28,127.31,127.4$, $128.0,128.06,128.09,128.12,129.0,129.0,129.4,130.0,132.2,132.4$, $132.5,134.1,134.4,134.5,134.9,135.3,135.5,139.9,141.8,158.1$, 158.9, 197.6; IR (neat): $v^{\sim}=2925,1670,1506,1244,748 \mathrm{~cm}^{-1}$; HRMS $\left(\mathrm{APCl}^{+}\right)$: calcd. for $\mathrm{C}_{36} \mathrm{H}_{27} \mathrm{O}_{3}[\mathrm{M}+\mathrm{H}]^{+}: 507.1960$; found: 507.1960 .

Oxidative aryl-aryl coupling leading to half HBC. Synthesis of half HBC 10aa is described as a typical procedure. To a mixed 1,2dichloroethane- $\mathrm{MeNO}_{2}$ solution $(10: 1,11 \mathrm{~mL})$ of $\mathrm{FeCl}_{3}(523 \mathrm{mg}, 3.22$ mmol) was added benzotriphenylene 6 aa $(46 \mathrm{mg}, 0.11 \mathrm{mmol})$ at $0{ }^{\circ} \mathrm{C}$ The resulting solution was stirred for $1 \mathrm{~h}$. $\mathrm{MeOH}$ was added to quench the reaction and organic materials were extracted with dichloromethane three times. The combined extracts were washed with brine and dried over anhydrous $\mathrm{Na}_{2} \mathrm{SO}_{4}$. After removal of the solvent under reduced pressure, the residue was purified by column chromatography on silica gel (dichloromethane) to give half HBC 10aa (38 $\mathrm{mg}, 84 \%$ yield) as a yellow solid

Dibenzo[fg,ij]naphtho[1,2,3,4-rst]pentaphene 10aa: ${ }^{1} \mathrm{H}$ NMR $(500 \mathrm{MHz}$, $\left.\mathrm{CDCl}_{3}\right): \delta=7.70(\mathrm{dd}, J=6.4,3.4 \mathrm{~Hz}, 2 \mathrm{H}), 7.71-7.77(\mathrm{~m}, 4 \mathrm{H}), 7.96(\mathrm{dd}, J$ $=7.9,7.9 \mathrm{~Hz}, 2 \mathrm{H}), 8.80(\mathrm{~d}, J=7.5 \mathrm{~Hz}, 2 \mathrm{H}), 8.82(\mathrm{~d}, J=7.9 \mathrm{~Hz}, 4 \mathrm{H})$, 8.94-9.00 (m, 2H), 9.11 (dd, $J=6.4,3.4 \mathrm{~Hz}, 2 \mathrm{H}) ;{ }^{13} \mathrm{C}$ NMR $(126 \mathrm{MHz}$, $\left.\mathrm{CDCl}_{3}\right): \delta=121.7,121.8,122.1,123.8,124.5,125.2,125.7,126.4,126.8$, $126.9,128.4,128.9,129.5,129.8,129.9,130.1,131.2$; IR (neat): $v^{\sim}=$ 1261, 1092, 1018, 796, $741 \mathrm{~cm}^{-1}$; HRMS $\left(\mathrm{APCl}^{+}\right)$: calcd. for $\mathrm{C}_{34} \mathrm{H}_{19}$ $[\mathrm{M}+\mathrm{H}]^{+}:$427.1487; found: 427.1477 .

7,16-Dihexyldibenzo[fg,ij]naphtho[1,2,3,4-rst]pentaphene 10ac: ${ }^{1} \mathrm{H}$ NMR $\left(500 \mathrm{MHz}, \mathrm{CDCl}_{3}\right): \delta=0.93(\mathrm{t}, J=6.8 \mathrm{~Hz}, 6 \mathrm{H}), 1.32-1.42(\mathrm{~m}, 8 \mathrm{H}), 1.47$ (tt, $J=7.6,7.2 \mathrm{~Hz}, 4 \mathrm{H}), 1.80(\mathrm{tt}, J=7.8,7.6 \mathrm{~Hz}, 4 \mathrm{H}), 2.85(\mathrm{t}, J=7.8 \mathrm{~Hz}$, $4 \mathrm{H}), 7.44(\mathrm{~d}, J=8.4 \mathrm{~Hz}, 2 \mathrm{H}), 7.60(\mathrm{dd}, J=6.5,3.1 \mathrm{~Hz}, 2 \mathrm{H}), 7.72$ (dd, $J=$ $7.8,7.8 \mathrm{~Hz}, 2 \mathrm{H}), 8.41(\mathrm{~s}, 2 \mathrm{H}), 8.53(\mathrm{~d}, J=8.0 \mathrm{~Hz}, 2 \mathrm{H}), 8.61(\mathrm{~d}, J=8.1 \mathrm{~Hz}$, $2 \mathrm{H}), 8.74(\mathrm{~d}, J=8.3 \mathrm{~Hz}, 2 \mathrm{H}), 9.00(\mathrm{dd}, J=6.4,3.4 \mathrm{~Hz}, 2 \mathrm{H}) ;{ }^{13} \mathrm{C}$ NMR $\left(126 \mathrm{MHz}, \mathrm{CDCl}_{3}\right): \delta=14.2,22.7,29.2,31.6,31.8,36.4,121.2,121.4$, $121.6,122.9,124.4,124.8,125.4,126.3,127.1,127.4,128.4,128.8$, 129.6, 129.7, 129.8, 131.0, 141.3; IR (neat): $v^{\sim}=2924,1466,1441,806$,
$750 \mathrm{~cm}^{-1}$; HRMS $\left(\mathrm{APCl}^{+}\right)$: calcd. for $\mathrm{C}_{46} \mathrm{H}_{43}[\mathrm{M}+\mathrm{H}]^{+}$: 595.3365; found: 595.3353.

7,16-Di-tert-butyldibenzo[fg,ij]naphtho[1,2,3,4-rst]pentaphene 10ad: ${ }^{1} \mathrm{H}$ NMR $\left(500 \mathrm{MHz} \mathrm{CDCl}_{3}\right): \delta=1.51(\mathrm{~s}, 18 \mathrm{H}), 7.62(\mathrm{dd}, J=6.5,3.3 \mathrm{~Hz}, 2 \mathrm{H})$, 7.73 (dd, $J=8.6,1.9 \mathrm{~Hz}, 2 \mathrm{H}), 7.89$ (dd, $J=7.9,7.9 \mathrm{~Hz}, 2 \mathrm{H}), 8.75(\mathrm{~d}, J=$ $2.0 \mathrm{~Hz}, 2 \mathrm{H}), 8.76(\mathrm{~d}, J=7.9 \mathrm{~Hz}, 2 \mathrm{H}), 8.81(\mathrm{~d}, \mathrm{~J}=8.0 \mathrm{~Hz}, 2 \mathrm{H}), 8.86(\mathrm{~d}, J=$ $8.6 \mathrm{~Hz}, 2 \mathrm{H}$ ), 9.09 (dd, J = 6.4, $3.4 \mathrm{~Hz}, 2 \mathrm{H}$ ); ${ }^{13} \mathrm{C}$ NMR $\left(126 \mathrm{MHz} \mathrm{CDCl}_{3}\right): \delta$ $=31.6,35.2,119.7,121.5,121.6,121.9,124.6,124.7,125.0,125.6$, $126.7,127.4,128.5,128.9,129.6,130.0,130.4,130.8,149.6$; IR (neat): $v^{\sim}=2956,2922,1259,1018,796 \mathrm{~cm}^{-1}$; $\operatorname{HRMS}\left(\mathrm{APCl}^{+}\right)$: calcd. for $\mathrm{C}_{42} \mathrm{H}_{35}$ $[\mathrm{M}+\mathrm{H}]^{+}:$539.2739; found: 539.2745 .

\section{Acknowledgements}

This research is supported by JSPS KAKENHI Grant Numbers JP18H04234 and JP19H02707. TOSOH FINECHEM COOPERATION is acknowledged for the generous gift of $\mathrm{CF}_{3} \mathrm{CH}_{2} \mathrm{I}$.

Keywords: aryne $\cdot$ fluorine $\cdot \mathrm{PAH} \cdot$ domino reactions $\bullet$ triphenylene

[1] a) R. G. Harvey Polycyclic Aromatic Hydrocarbons: Chemistry and Carcinogenicity, Cambridge University Press, Cambridge, 1991; b) R. G. Harvey Polycyclic Aromatic Hydrocarbons, Wiley-VCH, New York, 1997; c) J. C. Fetzer Large (C> = 24) Polycyclic Aromatic Hydrocarbons: Chemistry and Analysis, Wiley-Interscience, New York, 2000.

[2] a) J. E. Anthony, Chem. Rev. 2006, 106, 5028-5048; b) J. E. Anthony, Angew. Chem. Int. Ed. 2008, 47, 452-483; c) Y. Yamashita, Sci. Technol. Adv. Mater. 2009, 10, 024313; d) Y. Kubozono, X. He, S. Hamao, K. Teranishi, H. Goto, R. Eguchi, T. Kambe, S. Gohda, Y. Nishihara, Eur. J. Inorg. Chem. 2014, 38063819.

[3] a) D. J. Gundlach, Y. Y. Lin, T. N. Jackson, S. F. Nelson, D. G. Schlom, IEEE Electron Device Lett. 1997, 18, 87-89; b) Y. Y. Lin, D. J. Gundlach, S. F. Nelson, T. N. Jackson, IEEE Electron Device Lett. 1997, 18, 606-608; c) J. E. Anthony, J. S. Brooks, D. L. Eaton, S. R. Parkin, J. Am. Chem. Soc. 2001, 123, 9482-9483; d) V. C. Sundar, J. Zaumseil, V. Podzorov, E. Menard, R. L. Willett, T. Someya, M. E. Gershenson, J. A. Rogers, Science 2004, 303, 1644-1646; e) K. P. Weidkamp, A. Afzali, R. M. Tromp, R. J. Hamers, J. Am. Chem. Soc. 2004, 126, 12740-12741.

[4] a) H. Moon, R. Zeis, E.-J. Borkent, C. Besnard, A. J. Lovinger, T. Siegrist, C. Kloc, Z. Bao, J. Am. Chem. Soc. 2004, 126, 1532215323; b) M. Murai, H. Maekawa, S. Hamao, Y. Kubozono, D. Roy, K. Takai, Org. Lett. 2015, 17, 708-711; c) T. P. Nguyen, J. H. Shim, J. Y. Lee, J. Phys. Chem. C 2015, 119, 11301-11310; d) H. Okamoto, S. Hamao, R. Eguchi, H. Goto, Y. Takabayashi, P. Y.-H. Yen, L. U. Liang, C.-W. Chou, G. Hoffmann, S. Gohda, H. Sugino, Y.-F. Liao, H. Ishii, Y. Kubozono, Sci. Rep. 2019, 9, 4009.

[5] a) H. Okamoto, N. Kawasaki, Y. Kaji, Y. Kubozono, A. Fujiwara, M. Yamaji, J. Am. Chem. Soc. 2008, 130, 10470-10471; b) N. Kawasaki, Y. Kubozono, H. Okamoto, A. Fujiwara, M. Yamaji, App. Phys. Lett. 2009, 94, 043310-043310; c) Y. Wang, S. Di Motta, F. Negri, R. Friedlein, J. Am. Chem. Soc. 2011, 133, 10054-10057.

[6] a) S. Sahasithiwat, T. Mophuang, L. Menbangpung, S. Kamtonwong, T. Sooksimuang, Synth. Mater. 2010, 160, 11481152; b) J. Storch, J. Zadny, T. Strasak, M. Kubala, J. Sykora, M. Dusek, V. Cirkva, P. Matejka, M. Krbal, J. Vacek, Chem. Eur. J. 2015, 21, 2343-2347.

[7] a) Y. Yang, R. C. da Costa, M. J. Fuchter, A. J. Campbell, Nat Photonics 2013, 7, 634-638; b) Y. Yang, B. Rice, X. Shi, J. R Brandt, R. Correa da Costa, G. J. Hedley, D.-M. Smilgies, J. M. Frost, I. D. W. Samuel, A. Otero-de-la-Roza, E. R. Johnson, K. E. Jelfs, J. Nelson, A. J. Campbell, M. J. Fuchter, ACS Nano 2017, 11, 8329-8338; c) B. Rice, J. Nelson, L. M. LeBlanc, E. R. 
Johnson, A. Otero de la Roza, M. J. Fuchter, K. E. Jelfs, Nanoscale 2018, 10, 1865-1876.

[8] a) C. M. Buess, D. D. Lawson, Chem. Rev. 1960, 60, 313-330; b) P. J. Collings, M. Hird Introduction to Liquid Crystals: Chemistry and Physics, Taylor \& Francis, 1997; c) C. Tschierske, Ann. Rep. Prog Chem., Sect. C 2001, 97, 191-267.

[9] a) H. Pellissier, M. Santelli, Tetrahedron 2003, 59, 701-730; b) $\mathrm{H}$ H. Wenk, M. Winkler, W. Sander, Angew. Chem. Int. Ed. 2003, 42 502-528; c) D. Pérez, D. Peña, E. Guitián, Eur. J. Org. Chem 2013, 5981-6013; d) O. T. Dyan, G. I. Borodkin, P. A. Zaikin, Eur. J. Org. Chem. 2019, 7271-7306.

[10] a) A. Sygula, R. Sygula, P. W. Rabideau, Org. Lett. 2005, 7, 49995001; b) F. Furrer, A. Linden, M. C. Stuparu, Chem. Eur. J. 2013, 19, 13199-13206; c) D. Rodríguez-Lojo, D. Peña, D. Pérez, E. Guitián, Synlett 2015, 26, 1633-1637; d) T. Hosokawa, Y. Takahashi, T. Matsushima, S. Watanabe, S. Kikkawa, I. Azumaya, A. Tsurusaki, K. Kamikawa, J. Am. Chem. Soc. 2017, 139, 1851218521; e) M. Vilas-Varela, S. Fatayer, Z. Majzik, D. Pérez, E. Guitián, L. Gross, D. Peña, Chem. Eur. J. 2018, 24, 17697-17700.

[11] a) K. Fuchibe, Y. Mayumi, N. Zhao, S. Watanabe, M. Yokota, J. Ichikawa, Angew. Chem. Int. Ed. 2013, 52, 7825-7828; b) K. Fuchibe, Y. Mayumi, M. Yokota, H. Aihara, J. Ichikawa, Bull. Chem. Soc. Jpn. 2014, 87, 942-949; c) K. Fuchibe, H. Imaoka, J. Ichikawa, Chem. Asian J. 2017, 12, 2359-2363; d) K. Fuchibe, K. Shigeno, N. Zhao, H. Aihara, R. Akisaka, T. Morikawa, T. Fujita, K. Yamakawa, T. Shimada, J. Ichikawa, J. Fluorine Chem. 2017, 203, 173-184.

[12] For the synthesis of 1,1-difluoroallenes, see: a) M. Yokota, K Fuchibe, M. Ueda, Y. Mayumi, J. Ichikawa, Org. Lett. 2009, 11 3994-3997; b) K. Oh, K. Fuchibe, J. Ichikawa, Synthesis 2011, 881-886; c) K. Oh, K. Fuchibe, M. Yokota, J. Ichikawa, Synthesis 2012, 44, 857-861; d) K. Fuchibe, M. Abe, K. Oh, J. Ichikawa, Org Synth. 2016, 93, 352-366.

[13] a) B. E. Smart Organofluorine Chemistry, Principles and Commercial Applications, Plenum Press, New York, 1994; b) K. Uneyama Methods for Introduction of Fluorine-Functionality into Molecules, Blackwell Publishing, Oxford, 2006; c) J.-P. Bégué, D. Bonnet-Delpon Bioorganic and Medicinal Chemistry of Fluorine, Wiley, Hoboken, 2008.

[14] For our publications on the reactions via $\alpha$-fluoroarbocations, see for example: a) J. Ichikawa, M. Yokota, T. Kudo, S. Umezaki, Angew. Chem. Int. Ed. 2008, 47, 4870-4873; b) K. Fuchibe, H. Jyono, M. Fujiwara, T. Kudo, M. Yokota, J. Ichikawa, Chem. Eur. J. 2011, 17, 12175-12185; c) N. Suzuki, T. Fujita, J. Ichikawa, Org Lett. 2015, 17, 4984-4987; d) N. Suzuki, T. Fujita, K. Amsharov, J. Ichikawa, Chem. Commun. 2016, 52, 12948-12951; e) K. Fuchibe, R. Takayama, T. Yokoyama, J. Ichikawa, Chem. Eur. J. 2017, 23, 2831-2838; f) K. Fuchibe, H. Hatta, K. Oh, R. Oki, J. Ichikawa, Angew. Chem. Int. Ed. 2017, 56, 5890-5893; g) K. Fuchibe, R. Oki H. Hatta, J. Ichikawa, Chem. Eur. J. 2018, 24, 17932-17935; h) K. Fuchibe, G. Takao, H. Takahashi, S. ljima, J. Ichikawa, Bull. Chem Soc. Jpn. 2019, 92, 2019-2029.

[15] For the synthesis of triphenylenes, see: a) D. Perez, E. Guitian, Chem. Soc. Rev. 2004, 33, 274-283; b) C. Romero, D. Peña, D Pérez, E. Guitián, Chem. Eur. J. 2006, 12, 5677-5684.

[16] M. Grzybowski, K. Skonieczny, H. Butenschön, D. T. Gryko, Angew. Chem. Int. Ed. 2013, 52, 9900-9930.

[17] For the synthesis of hexabenzocoronenes, see: J. Wu, W. Pisula K. Müllen, Chem. Rev. 2007, 107, 718-747.

[18] ortho-Fluoro(halo)chrysenes could not be synthesized.

[19] a) T. Hamura, R. Nakayama, Chem. Lett. 2013, 42, 1013-1015. See also: b) S. Eda, F. Eguchi, H. Haneda, T. Hamura, Chem. Commun. 2015, 51, 5963-5966; c) R. Akita, K. Kawanishi, T. Hamura, Org. Lett. 2015, 17, 3094-3097.

[20] K. C. Caster, C. G. Keck, R. D. Walls, J. Org. Chem. 2001, 66, 2932-2936.

[21] M. Uchiyama, Y. Kobayashi, T. Furuyama, S. Nakamura, Y. Kajihara, T. Miyoshi, T. Sakamoto, Y. Kondo, K. Morokuma, J. Am. Chem. Soc. 2008, 130, 472-480.
[22] There have been several reports on the synthesis of half HBCs through construction of centeral benzene rings by Diels-Alder reaction. However, to the best of our knowledge, this is the first half HBC synthesis by Diels-Alder reaction of arynes. See: a) M. Müller, H. Mauermann-Düll, M. Wagner, V. Enkelmann, K. Müllen, Angew. Chem. Int. Ed. 1995, 34, 1583-1586; b) B. Alameddine, S. M. Caba, M. Schindler, T. A. Jenny, Synthesis 2012, 44, 19281934 ; c) B. Alameddine, R. S. Anju, F. Al-Sagheer, T. A. Jenny, New J. Chem. 2016, 40, 10363-10370. See also: d) A. K. Dutta, A. Linden, L. Zoppi, K. K. Baldridge, J. S. Siegel, Angew. Chem. Int. Ed. 2015, 54, 10792-10796; e) A.-K. Steiner, K. Y. Amsharov, Angew. Chem. Int. Ed. 2017, 56, 14732-14736; f) W.-J. Kong, L. H. Finger, J. C. A. Oliveira, L. Ackermann, Angew. Chem. Int. Ed. 2019, 58, 6342-6346.

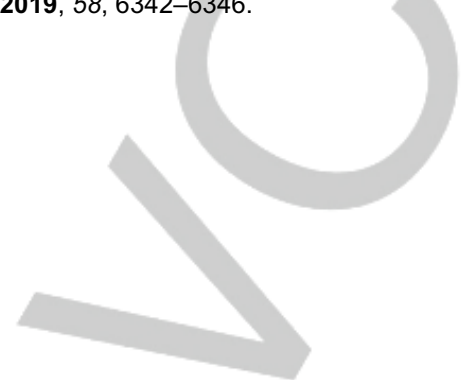




\section{Entry for the Table of Contents}
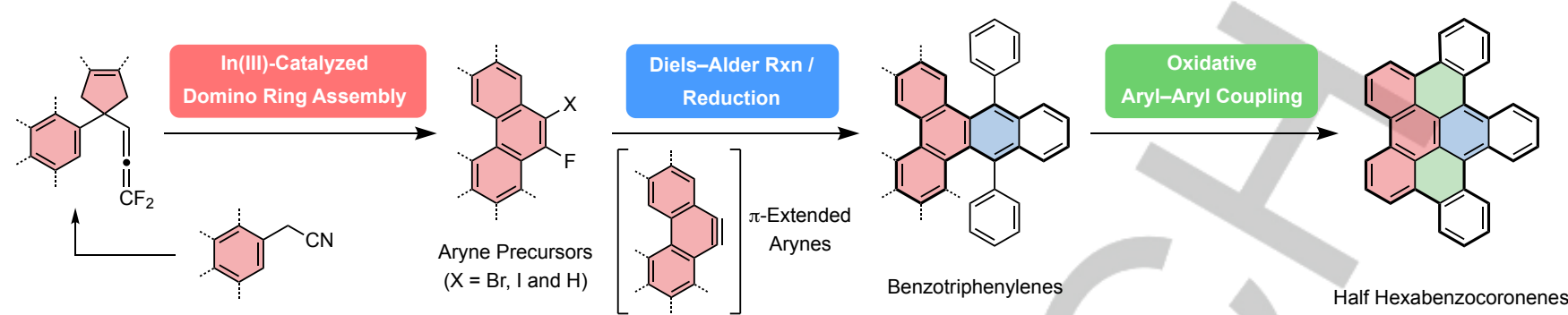

1,1-Difluoroallenes bearing a cyclopentene moiety and an aryl group underwent In-catalyzed domino ring assembly to afford aryne precursors such as ortho-fluoro(halo)phenanthrenes and fluoro[4]helicenes. Their elimination of XF generated $\pi$-extended arynes, whose Diels-Alder reactions with isobenzofurans followed by aromatisation furnished benzotriphenylenes. Their aryl-aryl coupling facilitated "half HBC" synthesis. 